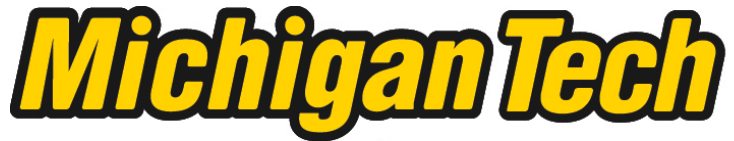 \\ Michigan Technological University Create the Future Digital Commons @ Michigan Tech
}

Dissertations, Master's Theses and Master's Reports - Open

Dissertations, Master's Theses and Master's

Reports

2011

Warming alters photosynthetic rates of sub-boreal peatland vegetation

Arvo Aljaste

Michigan Technological University

Follow this and additional works at: https://digitalcommons.mtu.edu/etds

Part of the Forest Sciences Commons

Copyright 2011 Arvo Aljaste

\section{Recommended Citation}

Aljaste, Arvo, "Warming alters photosynthetic rates of sub-boreal peatland vegetation", Master's Thesis, Michigan Technological University, 2011.

https://doi.org/10.37099/mtu.dc.etds/151

Follow this and additional works at: https://digitalcommons.mtu.edu/etds

Dart of the Forest Sciences Commons 


\title{
WARMING ALTERS PHOTOSYNTHETIC RATES OF SUB-BOREAL PEATLAND VEGETATION
}

\author{
By \\ Arvo Aljaste

\begin{abstract}
A THESIS
Submitted in partial fulfillment of the requirements for the degree of MASTER OF SCIENCE

Forest Ecology and Management
\end{abstract}

MICHIGAN TECHNOLOGICAL UNIVERSITY

2011

C2011 Arvo Aljaste 
This thesis, "WARMING ALTERS PHOTOSYNTHETIC RATES OF SUB-BOREAL PEATLAND VEGETATION," is hereby approved in partial fulfillment of the requirements for the Degree of MASTER OF SCIENCE IN FOREST ECOLOGY AND MANAGEMENT.

School of Forest Resources and Environmental Science

Signatures:

Thesis Advisor

Rodney A. Chimner

Thesis Co-Advisor

Eric Agestam

Committee member

Thomas G. Pypker

Committee member

Casey J. Huckins

Dean

Margaret R. Gale

Date 


\section{Table of contents}

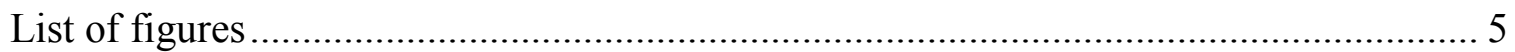

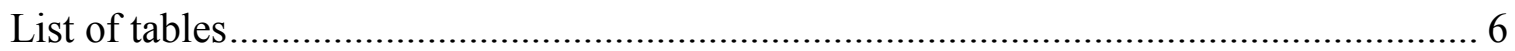

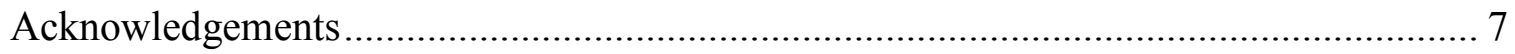

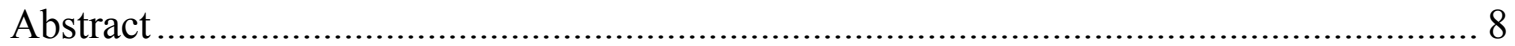

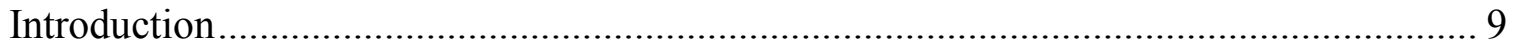

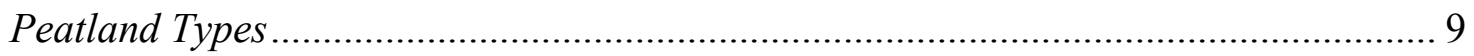

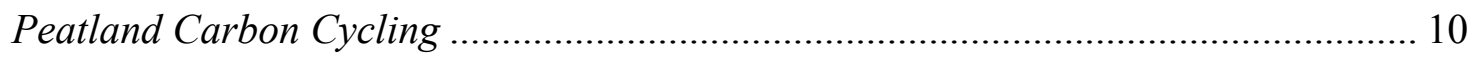

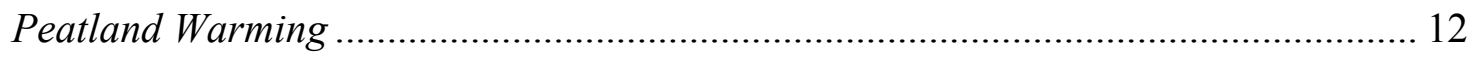

Methodology Background .................................................................................... 15

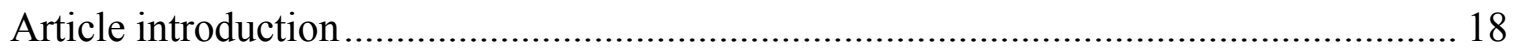

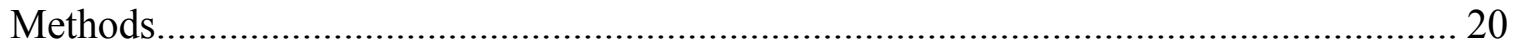

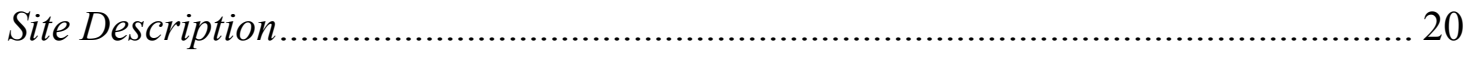

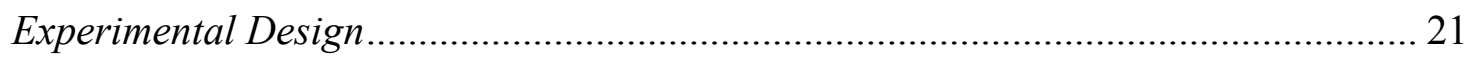

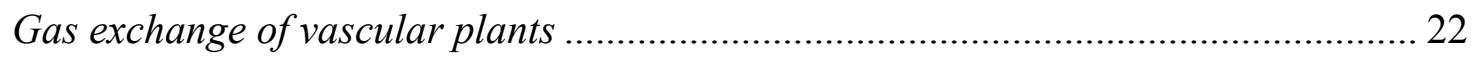

Gas exchange of Sphagnum moss ........................................................................ 23

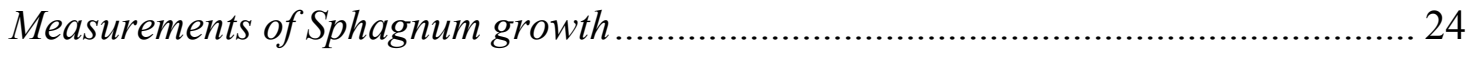

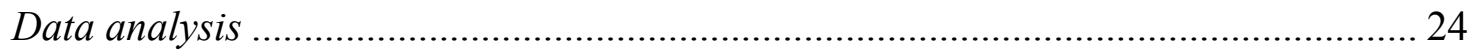

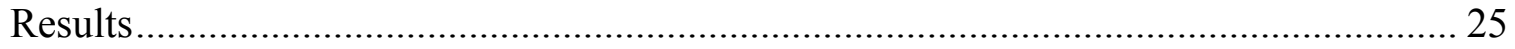




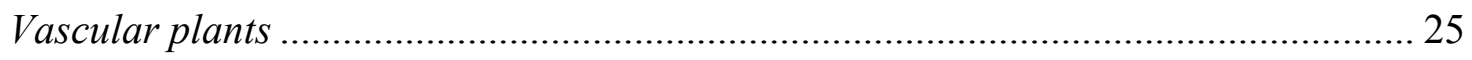

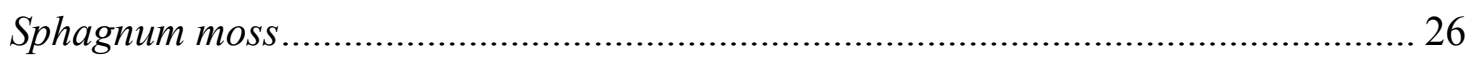

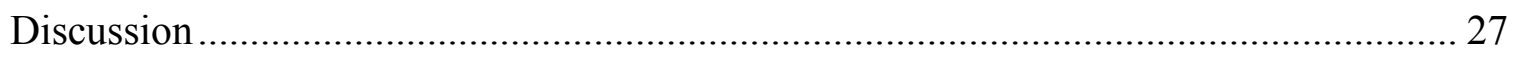

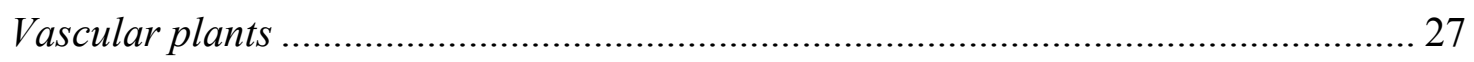

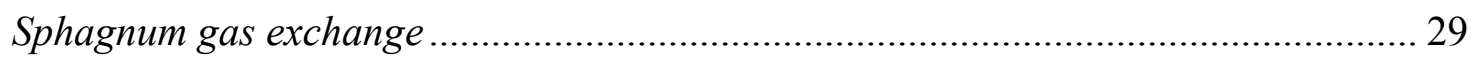

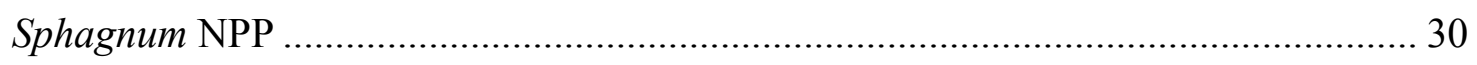

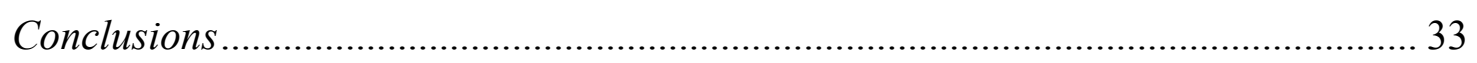

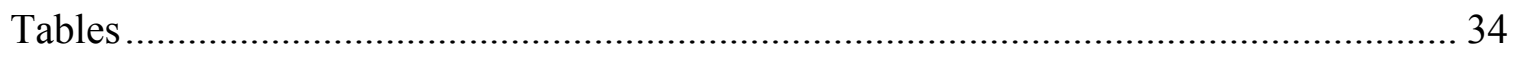

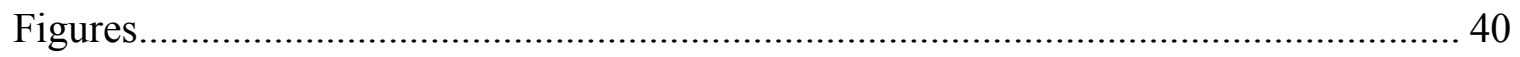

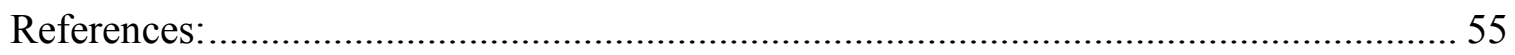




\section{List of figures}

Figure 1. Water table depth and precipitation amounts ................................................ 40

Figure 2. Average (se) $\mathrm{CO}_{2}$ uptake of Leatherleaf (Chamaedaphne calyculata) ............ 41

Figure 3. Correlation between water table depth and leatherleaf stomatal conductance. 42

Figure 4. Correlation between leatherleaf stomatal conductance and $\mathrm{CO}_{2}$ uptake.......... 43

Figure 5. Warming treatment effect on stomatal conductance of leatherleaf in lawns.... 44

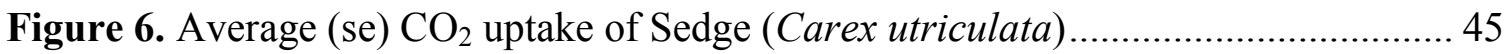

Figure 7. Average (se) $\mathrm{CO}_{2}$ exchange by Sphagnum moss .......................................... 46

Figure 8. Mean (se) Sphagnum biomass accumulation................................................ 47

Figure 9. Mean (se) biomass production of Sphagnum moss on hummocks................... 48

Figure 10. Mean (se) biomass production of Sphagnum moss on lawns........................ 49

Figure 11. Average volumetric water content (se) of Sphagnum moss in hummocks..... 50

Figure 12. Average volumetric water content (se) of Sphagnum moss in lawns............. 51

Figure 13. Correlation between volumetric water content and Sphagnum NEE lawns... 52

Figure 14. Sphagnum vapor pressure deficit (se) by date.............................................. 53

Figure 15. Sphagnum NEE in hummocks by date ....................................................... 54 


\section{List of tables}

Table1. Average percent (\%) cover of plant species................................................. 34

Table 2. ANOVA results for Leatherleaf $\mathrm{CO}_{2}$ uptake. .......................................... 35

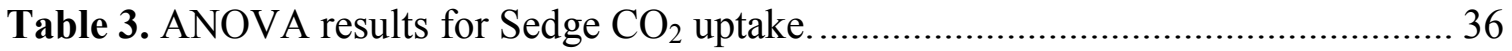

Table 4. ANOVA results for Sphagnum net ecosystem exchange (NEE) ..................... 37

Table 5. ANOVA results for Sphagnum Ecosystem respiration (ER) .......................... 38

Table 6. ANOVA results for mean Sphagnum biomass accumulation .......................... 39 


\section{Acknowledgements}

This thesis is a dual degree thesis in cooperation with both Michigan Technological University and Swedish Agricultural University

I would sincerely like to thank the EU-USA funded Atlantis program for making my stay abroad possible and giving me the possibility to make this thesis possible. I would also like to thank the Department of Energy, the National Institute of Climate Change Research and Ecosystem Science Center in Michigan Technological University for funding this research project.

My biggest gratitude goes to my advisor, Rod Chimner, for being an example from the beginning to the end of my stay on how to become a great scientist. But more than that, I admire his commitment to his family and his positive attitude to life.

Thank you, Eric Agestam, for being my co-advisor and for getting all the questions sorted for graduating in Sweden. Big thanks to my committee members Tom Pypker and Casey Huckins. And of course thanks to Maija Kovanen for helping out a lot during and after the stay in Finland.

My regards to my family and friends in Estonia for supporting me mentally while being abroad for such a long time. Big thanks to all the people in wetlands lab for assistance, know-how and for your time in helping out. And to all of the wonderful people I have met on the road for sharing the path with me and giving me the greatest years of my life. I love you all! 


\begin{abstract}
Boreal peatlands are important in the global carbon cycle. Despite covering only $3 \%$ of the global land area, peatlands store approximately one third of all soil carbon. Temperature is one of the major drivers in peatland carbon cycling as it affects both plant production and $\mathrm{CO}_{2}$ fluxes from soils. However, it is relatively unknown how boreal peatland plant photosynthesis is affected by higher temperatures. Therefore, we measured plant photosynthetic rates under two different warming treatments in a poor fen in Northern Michigan. Eighteen plots were established that were divided into three treatments: control, open-top chamber (OTC) warming and infrared (IR) lamp warming. Previous work at this site has shown that there was a significant increase in canopy and peat temperature with IR warming $\left(5^{\circ} \mathrm{C}\right.$ and $1.4^{\circ} \mathrm{C}$ respectively), while the OTC's had mixed overall warming. Plots were divided equally into lawns and hummocks. We measured mid-day carbon dioxide $\left(\mathrm{CO}_{2}\right)$ uptake on sedges (Carex utriculata), shrubs (Chamaedaphne calyculata) and Sphagnum mosses. Sphagnum moss net primary production (NPP) was also measured with cranked wires and compared with $\mathrm{CO}_{2}$ uptake.

Our results indicate that there was no significant difference in sedge $\mathrm{CO}_{2}$ uptake, while shrub $\mathrm{CO}_{2}$ uptake significantly decreased with warming. A significant increase occurred in Sphagnum moss gross ecosystem production (GEP), ecosystem respiration (ER) and net ecosystem exchange (NEE). Contrary to the positive $\mathrm{CO}_{2}$ exchange of Sphagnum, overall NPP decreased significantly in hummocks with both warming treatments. The results of the study indicate that temperature partly limits the photosynthetic capacity of plants in sub-boreal peatlands, but not all species respond similarly to higher temperatures.
\end{abstract}

Key words: Peatlands, $\mathrm{CO}_{2}$ uptake, Climate change, microtopography. 


\section{Introduction}

\section{Peatland Types}

Peatlands are wetlands where long-term average plant biomass accumulation exceeds decomposition rates (Crum 1992). Peatlands form because perennially saturated soils create anoxic conditions that hinder decomposition. Different countries have different requirements for peat thickness, with minimum thickness ranging between 30 $\mathrm{cm}$ to $50 \mathrm{~cm}$ (Gorham 1991). Peatland distribution is controlled primarily by climate and topography. Peatlands are most commonly found in cool and moist climates with low evapotranspiration and flat landforms (Sjörs 1980; Wieder and Vitt 2006). For instance, boreal and arctic peatlands (thickness $>30 \mathrm{~cm}$ ) cover $3.5 \times 10^{5} \mathrm{~km}^{2}$, or about $90 \%$ of all peatlands globally (Charman 2002).

Peatlands are often divided into two main types based on source of water and nutrients (Charman 2002). Peatlands that receive all of their water and nutrients from precipitation are called ombrotrophic peatlands, or bogs (Bridgham et al. 1999). Since they are cut off from groundwater, which contains minerals, these peatlands are characterized by low $\mathrm{pH}$, low base cation $\left(\mathrm{Ca}^{2+}, \mathrm{Mg}^{2+}, \mathrm{K}^{+}, \mathrm{Na}^{+}\right)$content and low nutrient levels (Zoltai and Vitt 1995; Wheeler and Proctor 2000). As a result, they have vegetation that is able to tolerate nutrient poor and acidic conditions and are characterized by the dominance of Sphagnum mosses. Peatlands that receive at least a part of their water from groundwater are called minerotrophic peatlands, or fens (Wieder and Vitt 2006). These peatlands have higher concentrations of nitrogen and phosphorus, base cations, and greater $\mathrm{pH}$ due to inflow of groundwater (Bridgham et al. 2001). Minerotrophic fens are dominated by plants which are not able to tolerate acidity like brown mosses and many types of sedge. Bogs have $\mathrm{pH}$ usually $<4.0$, while fens have $\mathrm{pH}>4.0$ and are divided into poor fens, intermediate fens and rich fens based upon their $\mathrm{pH}$ and base cation content (Wheeler and Proctor 2000). Poor fens are acidic, Sphagnum dominated but have some influx of ground water (Zoltai and Vitt 1995). Intermediate fens and rich fens have 
$\mathrm{pH}>5.5$ and are dominated by plants which do not tolerate acidity and lack significant cover of Sphagnum (Wieder and Vitt 2006).

\section{Peatland Carbon Cycling}

Peatlands are globally important in the terrestrial carbon cycle. What makes these ecosystems special is not their production rates, but the continuous imbalance between the production and decomposition, which over long time periods has resulted in very large carbon pools (Wieder and Vitt 2006). About 98.5\% of carbon in peatlands occurs in the form of peat, while the rest is found in vegetation (Gorham 1991). Boreal peatlands cover $3 \%$ of the global land mass, $\left(\sim 330,000 \mathrm{~km}^{2}\right)$ (Gunnarsson 2005$)$, but store about one third of all terrestrial soil carbon (Moore et al. 1998). Boreal peatlands accumulate

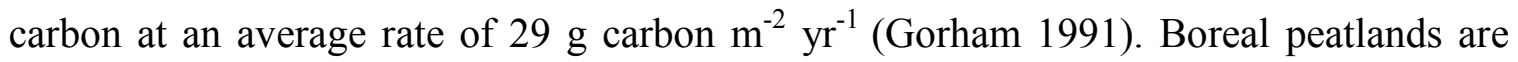
found within the boreal climatic zone and have been developing since the end of the last ice age (Gignac et al. 1998) and have accumulated 300-450 x $10^{15}$ grams of carbon during this period (Gorham 1991). This is about the same amount as currently stored in atmosphere (Houghton et al. 1990), and twice as much as forest biomass contains globally (Parish et al. 2008). Boreal peatlands have lower values of primary production compared to other ecosystems in the same climatic region. The most important plant genus in terms of carbon storage is Sphagnum (Clymo 1970), which contributes the majority of aboveground production in nutrient poor systems like bogs and poor fens, averaging $259 \mathrm{~g} \mathrm{~m}^{-2} \mathrm{yr}^{-1}$ (Weltzin et al. 2000) compared to average boreal forest biomass accumulation of $424 \mathrm{~g} \mathrm{~m}^{-2} \mathrm{yr}^{-1}$ (Gower et al. 2001).

The imbalance between production and decomposition itself is fragile. Around $90 \%$ of the carbon accumulated annually by plants is lost through decomposition, resulting in only $10 \%$ of plant biomass being stored over longer time periods (Gorham 1988; Vasander 1982). Peatlands are therefore sensitive to decreases in net primary production (NPP) or increases in ecosystem respiration (ER), which is the main loss of carbon to the atmosphere (Dorrepaal et al. 2009). Shifts in the carbon balance of these 
ecosystems could start releasing stored carbon back in the atmosphere as $\mathrm{CO}_{2}$; further accelerating the "greenhouse effect". For example, a $1^{\circ} \mathrm{C}$ increase was found to raise ER rates $56 \%$,with $69 \%$ of this increase coming from the bottom of the active layer in a permafrost peatland (Dorrepaal et al. 2009).

Primary productivity is the major input of carbon to a peatland (Rydin and Jeglum 2006). Net primary production is defined as a difference between gross primary production, total amount of organic carbon fixed by a plant, and autotrophic respiration which is the total amount of carbon lost by a plant (Woodwell and Whittaker 1968). Plants acquire carbon from $\mathrm{CO}_{2}$ taken up through photosynthesis (Lambers et al. 1998). The amount of $\mathrm{CO}_{2}$ assimilated by a vegetated surface is called gross ecosystem production (GEP) (Wofsy et al. 1993). For photosynthesis to occur, plants need sufficient source of water, sunlight and $\mathrm{CO}_{2}$. Each plant species has different requirements for optimum photosynthesis to occur. Photosynthesis is influenced directly by the light intensity and air temperature, which alters vapor pressure deficit, electron transport rate and photosynthetic enzyme production (Lloyd and Farquhar 2008). Light intensity (irradiance) relates to photosynthesis through the amount of captured photons (units of light), greater irradiance results in enhanced $\mathrm{CO}_{2}$ uptake (Lambers et al. 1998). Therefore if warming enhances photon capture, plant is able to fix more $\mathrm{CO}_{2}$ resulting in higher net biomass production.

Carbon outputs from peatlands are from efflux of $\mathrm{CO}_{2}$, methane and leaching of dissolved organic carbon (Davidson and Janssens 2006). Some of the carbon plants fix through photosynthesis is lost through plant respiration, defined as autotrophic respiration (Lambers et al. 1998). Heterotrophic respiration is a combination of fungal and microbial respiration and other organic matter decaying organisms (Shaver et al. 2000). Autotrophic and heterotrophic respiration together form ecosystem respiration, which is the total amount of $\mathrm{CO}_{2}$ lost from an ecosystem at a given time period (Davidson and Janssens 2006; Moore et al. 1998). Net ecosystem exchange (NEE) is the difference between the carbon gained by an ecosystem (GEP) minus the loss of carbon from ER. 


\section{Peatland Warming}

Increased greenhouse gas concentrations are expected to increase surface temperatures and alter regional precipitation patterns (IPCC 2007). It is predicted that higher concentrations of atmospheric $\mathrm{CO}_{2}$ concentrations will lead to greater photosynthesis and plant growth in most ecosystems (Norby et al. 2001), in nutrient poor ecosystems, increased $\mathrm{CO}_{2}$ concentration are predicted to have negligible effect on NPP (Hoosbeek et al. 2001).

Boreal peatlands are ecosystems characterized by generally low temperatures, short growing seasons, and low soil nutrient contents (Arft et al. 1999). Average global temperatures are predicted to increase $0.6-6^{\circ} \mathrm{C}$ by the end of $21^{\text {st }}$ century compared with the temperatures a century before (IPCC 2007). The greatest increases are predicted to occur at high latitudes of the Northern Hemisphere, especially in the arctic, where temperature increase could be even higher than average (Houghton et al. 1990; Houghton et al. 1995; Maxwell and Barrie 1989). Higher temperatures in northern peatlands could be seen as a large-scale disturbance with implications on growing conditions of the plants (Alm et al. 1999). Higher temperatures have the potential to increase evapotranspiration rates, which will lower water table and make oxygen more available for microbial decomposition (Faubert 2004; Gorham 1991). Both plant and soil microbial respiration rates could be positively influenced by higher temperatures (Dorrepaal et al. 2009). Heterotrophic respiration counts for $80 \%$ of soil respiration and increases more than autotrophic respiration in short time scale warming experiments (Melillo et al. 2002). Plant production could also be influenced either positively or negatively by increasing temperatures. Boreal peatlands are therefore, sensitive to either increases in decomposition or decreases in plant production (Wieder 2001), and could shift from carbon sinks to sources (Hoosbeek et al. 2001). If decomposition values exceed the $\mathrm{CO}_{2}$ uptake by plants, the carbon released to the atmosphere may result in positive feedback of rising $\mathrm{CO}_{2}$ concentrations in atmosphere (Oechel et al. 1993). Increase in both 
temperature and ER through lowered water tables will result in increased $\mathrm{CO}_{2}$ emissions to the atmosphere (Moore et al. 1998). It has been suggested that daytime $\mathrm{CO}_{2}$ uptake will be influenced less by temperature than ER (Houghton and Woodwell 1989). Therefore, peat accumulation in most sub-boreal peatlands may decrease or even cease (Gignac and Vitt 1994).

Peatlands at the southern end of boreal region (sub-boreal) could be especially vulnerable to climate change. The plant communities in these peatlands are accustomed to a moist and cold climate, and increasing temperature could affect their growing conditions. As the boreal forest zone is predicted to move northwards, and boreal peatlands are highly linked with the boreal forest zone (Gignac et al. 1998), peatland distribution could move northwards too. This was illustrated by (Prentice et al. 1991), who used a forest succession model to predict that in central Sweden boreal zone evergreen trees like Norway spruce (Picea abies) will be replaced by broadleaved temperate trees like beech (Fagus sylvatica) and common oak (Quercus robur), which require longer growing season and higher summer temperatures. Similarly, boreal peatland plants in sub-boreal zone could already be at their temperature threshold and any increase in temperature could result in northward movement of peatlands and changes of species composition of peatlands in former sub-boreal zone. It has been shown that with increased temperatures at high latitudes, areas currently unvegetated will have plant cover (Myneni et al. 1997), giving further evidence to movement of ecosystems following suitable conditions. Species will follow the shifting climate northwards to higher latitudes as much as the dispersal and resource availability allow (Aerts et al. 2006).

Water table level is the most important factor controlling decomposition rates in peatlands (Bridgham and Richardson 2003). Upland soils are well aerated and therefore have low carbon stocks (Davidson and Janssens 2006). If rising temperatures or lower precipitation in the future lower the water table, increased microbial activity is expected to occur in the peat (Clymo 1992). Plant photosynthesis responds to temperature almost immediately, which can result in higher NPP (Shaver et al. 2000). Higher temperatures 
have positive effects on overall soil respiration rates (Lloyd and Taylor 1994) since microbial decomposition is reduced under low temperatures (Allison et al. 2010; Woodwell and Whittaker 1968). In nutrient poor ecosystems like boreal peatlands, warming enhanced soil respiration results in higher nutrient availability over long time periods (Chapin 1983). Plant growth in most boreal peatlands is nutrient limited (Shaver et al. 2000), especially by nitrogen (Aerts et al. 1992). Most of the nutrients are tied up in plant biomass or peat. Nutrient availability is crucial for plant growth and warming induced changes in nutrient dynamics could result in changes in plant communities (Aerts et al. 2006). Nitrogen availability could increase through faster decomposition of organic matter (Shaver et al. 2000). Nitrogen availability has also increased through increased atmospheric $\mathrm{N}$ deposition (Aber et al. 1998). Increased $\mathrm{N}$ supply possesses more positive growth response on fast growing sedges and deciduous shrubs and decreases the abundance of slow growing mosses (Aerts et al. 2006). If plant species composition changes, so does litter composition and quality. Tissue quality (e.g. cellulose, lignin and nutrient composition) can be more important on decomposition rates than temperature or $\mathrm{pH}$ (Bartsch and Moore 1985). For example, because of their low tissue quality, Sphagnum species decompose more slowly than sedges (Toet et al. 2006). This is one of the reasons why Sphagnum spp. is one of the major peat forming plant genus and its remains store more carbon than any other plant genus on the globe (Clymo 1970). Peatlands dominated by Sphagnum mosses typically store more carbon than sedge dominated peatlands (Thormann and Bayley 1997). Sphagnum has unique properties in acidifying the substrate it is living in, resists decay, and being able to live in extremely nutrient poor conditions (Clymo 1964; Verhoeven and Liefveld 1997). Sphagnum's ability to acidify it's environment is thought to help it reduce the competition and gain competitive advantage (Andrus 1986). In boreal peatlands, vascular plant growth is limited by presence of Sphagnum, which dominates the lower layer of vegetation (Arft et al. 1999). Vascular plants have to invest into height growth not to become overgrown by Sphagnum (Rydin 1997). Therefore, shifts in species composition could result in peatland transformation from carbon sink to source if Sphagnum is outcompeted with sedges, 
shrubs or other mosses that are able to respond more rapidly to available nutrients, decay at faster rates, and do not acidify the soil (Toet et al. 2006).

Net primary production, increment of organic matter over time, is the most common metric to quantify warming on peatland plants (Dorrepaal et al. 2004; Szumigalski and Bayley 1997). Probable reasons for using NPP is because of limited accessibility of many arctic and boreal peatlands, and NPP measurements can be done with few field days. However, NPP measurements do not allow for monitoring short-term plant physiological responses to changes in temperature. Because NPP measurements may miss smaller time scale changes in plants, like reduced photosynthesis due to desiccation, $\mathrm{CO}_{2}$ flux measurements (leaf or ecosystem level) are commonly conducted to quantify these processes. The common method for measuring $\mathrm{CO}_{2}$ exchange between an ecosystem and the atmosphere has been to use small chambers (Alm et al. 1999; Gunnarsson et al. 2004; Kivimaki et al. 2008; Laine et al. 2007; Moore et al. 2002). These chambers allow monitoring photosynthesis and respiration of peatlands at community scale, which can thereafter be extrapolated to bigger areas. The problem with the method is that it neglects the response of individual plant groups within that community. Measuring $\mathrm{CO}_{2}$ uptake on a plant level gives the opportunity to quantify the differences between species or plant groups within the community. This is helpful in determining the possible shift in species composition in the future.

\section{Methodology Background}

In our study, we categorized plants as either woody (shrubs), graminoids (sedges) or bryophytes (Sphagnum spp.) to quantify changes in $\mathrm{CO}_{2}$ uptake under increased temperature.

How peatlands and peatland plants will behave under future climates has been under intensive study since it was realized how important peatlands are to the global carbon cycle. Artificial warming is the most common method used to study the effect of 
warming on ecosystem processes in peatlands (Arft et al. 1999; Marion et al. 1997). Artificial warming can be divided into two functionally different groups, active and passive. Active treatments use an artificial energy source to heat the soil or plant canopy (Aronson and McNulty 2009). Passive warming treatments utilize the suns energy to heat the canopy during the daytime and reduce heat loss during the night (Marion et al. 1997). In our study, we used standard ITEX (International Tundra Experiment) (Henry and Molau 1997) passive warming open top chambers (OTC's) and active warming infra-red (IR) lamps (Aronson and McNulty 2009) as treatments to monitor changes in plant $\mathrm{CO}_{2}$ uptake. IR lamps are elevated above the vegetation and distribute IR energy evenly to the canopy, while OTC's act as a greenhouse that is open at the top. They trap the IR wavelengths and reduce their re-radiation back to the atmosphere further warming the air inside the chamber (Marion et al. 1997). Although OTC's alter air temperature, they have relatively little impact on disturbing gas exchange, light and moisture (Arft et al. 1999). The IR lamps were constantly on during the growing season and warmed the plots during days and nights, whereas OTC's provide heating effect only during daytime. Since global temperature increase will raise nighttime temperatures (Luxmoore et al. 1998), it has been suggested that IR-lamps are more accurate in simulating future higher temperatures (Aronson and McNulty 2009). In Arctic peatlands, OTC's have been shown to increase the average temperature by about $2{ }^{\circ} \mathrm{C}$ (Marion et al. 1997). Two functionally different warming treatments enabled us to monitor the differences these two treatments were having on vegetation $\mathrm{CO}_{2}$ uptake. Changes in basic metabolism of a plant like acclimation to temperature occurs within a year (Shaver et al. 2000). Therefore short time period warming experiments enable monitoring plant physiological changes without influencing long term changes in the ecosystem like soil nutrient availability.

Several different methods have been used to measure $\mathrm{CO}_{2}$ exchange of plants, soil or the whole ecosystem. They all follow the same basic concept of analyzing the incoming and outgoing gas concentrations in the air and velocity of air movement between ecosystem and atmosphere. Eddy covariance towers are the primary means for monitoring the whole ecosystem fluxes (Baldocchi 2003). Since eddy covariance towers 
require uniform vegetation structure, flat landforms, big land areas and are biased during the nighttime they are unsuitable for use in all ecosystems (Baldocchi 2003). They cannot also be used for small experiment units with many treatments (Sullivan et al. 2008). Therefore manual chambers are often used to monitor smaller areas and areas with less uniform landscapes (Oechel et al. 1993). These kinds of chambers enable monitoring of differences in gas concentrations and humidity within the chamber. Chambers are put on top of the soil with vegetation enclosed into it, gas is directed into it while air is circulated at constant speed to mix the air (Vourlitis et al. 1993). Infra-red gas analyzer measures the difference between incoming and outgoing $\mathrm{CO}_{2}$ concentration in the chamber and calculates flux rates (Vourlitis et al. 1993). The reduction in gas concentration $\left(\mathrm{CO}_{2}\right)$ indicates uptake by plant photosynthesis from within the chamber. Manual chamber techniques have been found to give comparable results with eddy covariance method (Oechel et al. 1998).

We separated our treatments equally between two microtopographic features, hummocks and lawns. Their importance comes from the height of the water table, which influences soil moisture, biogeochemical cycling, and species composition (Moore et al. 2002). Hummocks are elevated higher up from the water table than lawns and typically have higher vascular plant biomass and less Sphagnum dominance (Vasander 1982). Hummocks are $20-50 \mathrm{~cm}$ above the water table, whereas lawns are only 0-10, and during some part of the growing season might even be submerged by water. Hummocks and lawns tend to have different Sphagnum moss composition and growth forms. At our study site, the species dominating the hummocks, Sphagnum fuscum, was rarely found on lawns. Microtopography is vitally important in determining Sphagnum growth and decomposition (Wieder and Vitt 2006). Sphagnum is dependent on the height of the water table and moisture content of the capitulum determines the growth rate of Sphagnum. Lawn species tend to have higher growth rates as illustrated by (Weltzin et al. 2001), who found that lawn species showed $100 \%$ higher primary production than hummock species and $50 \%$ higher production than intermediate microtopography. Since hummock Sphagnum species are farther away from the water table and they have no roots, they 
utilize their better capillary water transport and have denser growing forms than lawn species (Murray et al. 1989; Wieder and Vitt 2006). Sphagnum species are also known for their water holding capacity as they can hold up to 25 times more water than their own weight (Clymo and Hayward 1982). Even though the higher production in hollows could indicate that the microtopography would eventually become evened out, the hummock hollow dynamics seem to be maintained by lower decomposition rates of hummock species (Rochefort et al. 1990).

\section{Article introduction}

Boreal peatlands have accumulated vast amounts of carbon (300-450 Pg) since the end of the last ice age (Gorham 1991). Even though they only cover 3\% of the global land area (Gunnarsson 2005), they store about one-third of all terrestrial soil carbon (Moore et al. 1998). Carbon accumulates as peat when long-term plant productivity exceeds decomposition rates (Crum 1992; Gorham 1991). Temperature is one of the major drivers in peatland carbon cycling as it affects both plant production and decomposition; either of which could shift peatlands from a carbon sink to source (Hoosbeek et al. 2001). Average global temperatures are predicted to increase $0.6-6^{\circ} \mathrm{C}$ by the end of $21^{\text {st }}$ century compared with the temperatures a century before (IPCC 2007). The greatest increases are predicted to occur at high latitudes of the Northern Hemisphere, especially in the arctic (Houghton et al. 1990; Houghton et al. 1995; Maxwell and Barrie 1989).

The southern end of the boreal zone might also be sensitive to warming since peatlands closely follow geographic placement of boreal forests and its ecotone (Gignac et al. 1998). Since the southern boundary of boreal peatlands will move northwards (Gignac et al. 1998), the peatland plants already at their higher temperature threshold could experience considerable biotic responses to temperature (Callaghan and Jonasson 1995). Warming could therefore, cause shifts in vegetation with cold tolerant species 
moving northwards. For instance (Prentice et al. 1991) used computer based forest succession model and predicted that in central Sweden boreal zone evergreen trees, like Norway spruce (Picea abies), are being replaced by broadleaved temperate trees like, beech (Fagus sylvatica) and Common oak (Quercus robur), that require longer growing season and higher summer temperatures.

Both plant production and peat decomposition influence peat growth (Wieder 2001). Peat respiration (heterotrophic and autotrophic combined) has been shown to increase with rising temperatures (Chapman and Thurlow 1996; Chapman and Thurlow 1998), which will increase $\mathrm{CO}_{2}$ released from peatlands to the atmosphere. However, this additional loss of carbon could be offset by increased plant photosynthesis, which responds positively to higher temperatures (Shaver et al. 2000). Therefore, understanding how rates of photosynthesis will respond to warming in peatlands is vital to predict and model changes from climate change.

Experimental warming has been the major tool used to study the response of plant communities to warming (Arft et al. 1999; Weltzin et al. 2000). Experimental warming is divided into two functionally different types, active and passive (Aronson and McNulty 2009). Active treatments use an artificial source of energy to heat the soil or plant canopy, the most common example being infra-red (IR) lamps (Aronson and McNulty 2009). Passive warming treatments, such as open top chambers (OTC's), utilize the sun's energy by heating the canopy during the daytime and reducing heat loss during the night (Marion et al. 1997). However, it is unclear how these different types of warming affect plant photosynthesis and carbon cycling.

Therefore, the objective of this study was to test how $\mathrm{CO}_{2}$ uptake of a sedge, shrub, and Sphagnum mosses respond to two different experimental warming treatments. We hypothesize that: 1) Warming will increase $\mathrm{CO}_{2}$ uptake of sedges and shrubs since they have been found to grow faster on drier, more aerated soil, 2) The $\mathrm{CO}_{2}$ uptake of Sphagnum moss will decrease because the mosses are at their southern boundary and warmer conditions will increase respiration more than photosynthesis, and 3) the IR- 
warming lamps will have a larger influence on $\mathrm{CO}_{2}$ uptake than OTC's since they warm plots $24 \mathrm{~h}$ per day and therefore influence soil temperatures more.

\section{Methods}

\section{Site Description}

We conducted a field experiment to test the influence of two different types of warming (IR-lamps vs. OTC'S) on peatland carbon cycling. The study occurred in a poor fen in Pequaming $\left(46.85^{\circ} \mathrm{N} 88.37^{\circ} \mathrm{W}\right.$, elevation $\left.193 \mathrm{~m}\right)$, in the western half of Michigan's Upper Peninsula. The poor fen is 170 ha in size (EPA 2010), and occurs in a tombolo on the Keweenaw Bay, Lake Superior. A tombolo forms when sediments from waves create a land bridge connecting an island to a mainland. The Pequaming tombolo has a ridge on both lake sides, which act as barriers that keep most of the lake water out of the tombolo (Boisvert 2009).

The growing season in this region is 110 to 130 days (Eichenlaub 1990), with average minimum winter temperature of $-17^{\circ} \mathrm{C}$ and average maximum summer temperature of $26^{\circ} \mathrm{C}$ (IDcide 2010). Mean annual precipitation ranges from 760 to 910 centimeters, with heavy lake-effect snowfalls up to 5 meters per year (Albert 1995).

Peat cores indicate that the peat is $200-250 \mathrm{~cm}$ thick with a ${ }^{14} \mathrm{C}$ basal age of 2,225 +/- 105 years, consisting of humic Carex and Sphagnum remains (Boisvert 2009). The bottom layer of peat from 110-200 cm is mainly remnants of Carex ssp. The upper layer of peat (20-110 cm) is mostly Sphagnum with some undecomposed Carex ssp. (Boisvert 2009). Peat humification increased with increasing peat depth, with the uppermost $20 \mathrm{~cm}$ of peat consisting of undecomposed woody material and Chamaedaphne calyculata, Carex ssp. and Sphagnum moss.

Vegetation composition was surveyed during the summer of 2009 using a grid intercept method in the middle of each plot. A $1 \mathrm{~m}$ x $1 \mathrm{~m}$ grid was used with 100 points in each plot. An aluminum frame with a movable crossbar mounted with laser was used 
for sampling. All vascular plants and bryophytes hit by a laser pointer were identified, counted, and the number of hits was divided by 100 to get the percent cover of each species. Vascular plants and bryophytes were treated as two different vegetation layers, both summing up to $100 \%$. In summary, vegetation at the site is similar to other poor fens in the region (Table 1). The main vascular plants on the hummocks were Chamaedaphne calyculata, Vaccinium oxycoccos and Picea mariana. The dominant vascular plants in the lawns were Vaccinium oxycoccos, Carex exilis, Carex oligosperma and Chamaedaphne calyculata. Sphagnum fuscum was the dominant moss on the hummocks, constituting almost $60 \%$ of the cover, followed by Sphagnum magellanicum and Sphagnum rubellum. Sphagnum rubellum was the most common bryophyte in the lawns followed by Sphagnum papillosum.

\section{Experimental Design}

Eighteen plots were established in 2008 and divided into three treatments with equal numbers of IR heating lamps (lamps), OTC's, and unwarmed control plots. The warming experiment ran from late 2008 through October 2010. The 6 replicates of each warming treatment were split equally among hummocks and lawns. Boardwalks were installed to all plots to minimize impacts.

Air and soil temperatures were manipulated on six lamp plots by using adjustable, thermal infrared heating lamps [ $2 \mathrm{~m}$ in length, Kalglo Inc. IR lamps $(120 \mathrm{~V}, 1500 \mathrm{~W}$, $12.5 \mathrm{amps})]$ suspended $1.25 \mathrm{~m}$ above the moss surface. The lamps were operational 24 hours per day until the end of the growing season, from April to middle of October. Lamps were disassembled for the winter and stored in the lab until used again the following year.

Six plexiglass hexagon OTC's were designed according to ITEX (International Tundra Experiment) specifications (Henry and Molau 1997). The OTC's were $2.08 \mathrm{~m}$ wide from the bottom, $0.5 \mathrm{~m}$ in height, the sides were at $60^{\circ}$ angle and the open top was 
1.5 meters wide. OTC's were assembled and put out at the same time with lamps and disassembled in mid-October.

. IR lamps in our study increased average daily soil temperatures by about $1.4^{\circ} \mathrm{C}$ compared to OTC and control plots, but warmed even more during the night since the lamps were constantly operating (Chris Johnson, unpublished data).

Precipitation was measured on site using tipping-bucket rain gauge (TE525WS, Texas Instruments, Dallas, TX). Water table depth beneath the surface was monitored daily using a $10.16 \mathrm{~cm}$ wide and $1.5 \mathrm{~m}$ long PVC pipe well which had pressure transducers (Levellogger Junior, Solinst, Georgetown, Ontario) and a barometric logger (Baralogger Gold, Solinst, Georgetown, Ontario) installed into it. I-Buttons were installed to all plots (I-Buttons, Maxim Integrated Products, Sunnyvale, CA) $5 \mathrm{~cm}$ beneath the moss surface to monitor hourly temperature. Volumetric water content of the top $12 \mathrm{~cm}$ beneath the Sphagnum moss surface was measured manually with a HydroSense ${ }^{\circledR}$ Water Content Sensor (Campbell Scientific Inc., Australia).

\section{Gas exchange of vascular plants}

Gas exchange measurements of two different vascular plant species [leatherleaf (Chamaedaphne calyculata) and sedge (Carex utriculata)] were conducted. C. calyculata was chosen to represent shrub and $C$. utriculata sedge plant functional groups. The photosynthetic rate of these two species was measured over the growing season (end of April to the start of October 2010) using a Licor-6400 portable photosynthesis system (LI-COR Inc., Lincoln, NE, USA), equipped with a 6400-2B LED Light Source. The light source provided a constant photosynthetically active radiation (PAR) during the measurements and was set to $1500 \mu \mathrm{mol}$ photons $\mathrm{m}^{-2} \mathrm{~s}^{-1}$. The reference $\mathrm{CO}_{2}$ concentration was set to $400 \mu \mathrm{mol}$ per mole and the flow was set to a constant rate of 400 $\mu \mathrm{mol}$ per second. Leaf temperature and humidity were not controlled during the measurements. 
To determine leaf area in $\mathrm{cm}^{2}$, a requirement to calculate $\mathrm{CO}_{2}$ uptake, sedge leaf width was multiplied by $3 \mathrm{~cm}$ (longest side of IRGA's chamber). For leatherleaf, a common mathematical formula for ovals was used, where the area of the oval $\left(\mathrm{cm}^{2}\right)$ equals the width $(\mathrm{cm}) \times$ length $(\mathrm{cm}) \times$ 0.8. In most cases, the leaf area for the leatherleaf was relatively small, ranging from 0.7 to $3.36 \mathrm{~cm}^{2}$ with the mean $1.61 \mathrm{~cm}^{2}$. The average leaf area for sedges was more evenly balanced with values between $1.0-2.67 \mathrm{~cm}^{2}$ with a mean value of $1.72 \mathrm{~cm}^{2}$.

Measurements of vascular plant $\mathrm{CO}_{2}$ uptake were performed twice monthly between 9AM and 4PM. Cloudy and rainy days were avoided because the purpose was to diminish differences in environmental conditions surrounding the leaves between measurements and to simulate days when the leaf's photosynthetic capacity was high.

\section{Gas exchange of Sphagnum moss}

Due to difficulties with measuring Sphagnum spp. with a Licor 6400, chamber methods (Moore et al. 2002) were used instead to measure the gas exchange of Sphagnum moss. A small clear cylindrical plexiglass chamber was used with diameter of $10.46 \mathrm{~cm}$ and inner volume of $1.295 \mathrm{dm}^{3}$. Permanent round plastic collars (diameter of $10.46 \mathrm{~cm}$ and $10 \mathrm{~cm}$ deep) were installed into the peat at all plots, where the chamber was mounted on during the measurements. Sites for collars were chosen with very few vascular plants, but if any occurred in the collars they were picked or cut out to eliminate the photosynthetic gas exchange from vascular plants. The chamber was mounted with a battery operated fan for the mixing of air. Field measurements were done using an EGM4 environmental gas monitor (PP-Systems; Amesbury, Massachusetts, USA), which monitors the $\mathrm{CO}_{2}$ concentrations in the chamber. Both light (NEE) and dark measurements (ER) were carried out with the chamber. Before the measurements started, the chamber was placed on a collar and left to equilibrate until steady mixing ratio occurred. Typically for 20-30 seconds, which was indicated by steady increase or decrease in $\mathrm{CO}_{2}$ concentration inside the chamber (Chimner et al. 2010). NEE measurements were conducted first and lasted 120 seconds with readings recorded every 
5 seconds. After the measurement the chamber was taken off from the collar and flushed with ambient air for $\sim 2$ minutes since chambers cannot be held on place for extended periods because they start to alter evapotranspiration and temperature (Goulden and Crill 1997). Then the chamber was placed again on collar for ER measurement, covered with opaque cloth and same procedure was repeated. The Infra-Red Gas Analyzer (IRGA) uses the chamber volume and plot area to calculate the gas mixing ratio from linear or near-linear change in headspace $\mathrm{CO}_{2}$ concentration over the measurements period (Alm et al. 1999). GEP was later calculated by summing ER with the NEE (GEP=NEE+ER).

\section{Measurements of Sphagnum growth}

Sphagnum growth and production was measured in order to compare it with Sphagnum gas exchange measurements. Vertical growth of Sphagnum was measured by installing 48 cranked wires (Clymo 1970) per plot (864 total) on $30^{\text {th }}$ of May, 2010. Wires were measured again on October $15^{\text {th }}, 2010$ to quantify vertical growth during the growing season. Ten bulk density samples were collected for each five Sphagnum species present at plots, samples were oven dried at $70^{\circ} \mathrm{C}$ for 48 hours and weighed. Vertical growth of each Sphagnum species was correlated with bulk density samples of Sphagnum biomass to calculate the biomass increment (NPP) in $\mathrm{g}^{2}$.

\section{Data analysis}

Uptake of $\mathrm{CO}_{2}$ by plants was analyzed using three-way ANOVAs with treatment, species and topography set as independent variables. A separate two-way ANOVA was run for sedge and leatherleaf with topography and treatment set as independent variables. To measure treatment effect for Sphagnum growth, one-way ANOVA was used. All analyses were carried out using Systat statistical software (Systat Software, Inc., Chicago, IL). 


\section{Results}

The summer of 2010 had lower than average precipitation during July and August. This resulted in continuous water table drawdown through the season until the beginning of September (Figure 1). Photosynthetic uptake of vascular plants dropped by the middle of September while Sphagnum moss remained photosynthetically active until October (data not shown). IR-lamps raised the average soil temperature at $5 \mathrm{~cm}$ depth in 2010 summer months by more than $1.4^{\circ} \mathrm{C}$ and also increased canopy temperatures compared to control plots. OTC's had similar soil temperatures compared to control plots but experienced small cooling effect on mid-days (Chris Johnson, unpublished data).

\section{Vascular plants}

Average $\mathrm{CO}_{2}$ uptake of leatherleaf was not significantly different (Table 2) between the hummocks and lawns, averaging $9.8 \mu \mathrm{mol}$ of $\mathrm{CO}_{2} \mathrm{~m}^{-2} \mathrm{~s}^{-1}$ (Figure 2). The control plots had the highest average rate of $\mathrm{CO}_{2}$ uptake over the growing season (9.58 $\mu \mathrm{mol}$ of $\mathrm{CO}_{2} \mathrm{~m}^{-2} \mathrm{~s}^{-1}$ ) (Figure 2). Warming was found to significantly lower $\mathrm{CO}_{2}$ uptake $\left(\mathrm{P}=0.049\right.$, Figure 2), averaging $8.20 \mu \mathrm{mol}$ of $\mathrm{CO}_{2} \mathrm{~m}^{-2} \mathrm{~s}^{-1}$ under OTC treatment and 7.78 $\mu \mathrm{mol}$ of $\mathrm{CO}_{2} \mathrm{~m}^{-2} \mathrm{~s}^{-1}$ with the lamp treatment. Water table depth was correlated with leatherleaf stomatal conductance (Figure 3), and $\mathrm{CO}_{2}$ uptake by leatherleaf (Figure 4). Stomatal conductiance of leatherleaf in lawns tended to be lower with warming, but not significantly $(\mathrm{P}=0.2$, Figure 5$)$.

Average $\mathrm{CO}_{2}$ uptake of the sedge in the control plots $(8 \mu \mathrm{mol})$ was found to be slightly lower than the leatherleaf control plots (Figure 6). Average $\mathrm{CO}_{2}$ uptake was slightly greater in the hummocks than lawns, but the difference was not significant. There were also no significant differences found in $\mathrm{CO}_{2}$ uptake with warming, nor a warming $\mathrm{x}$ microtopography interaction (Table 3). 


\section{Sphagnum moss}

GEP of Sphagnum was not significantly different between lawns and hummocks (Figure 7). Pooled across microtopography, GEP was significantly greater under the lamps compared to the unwarmed control. In fact, GEP was almost 3 times as large. However, there was no significant difference between the OTC's and controls (Figure 7).

Similar to GEP, ER was significantly greater under lamps compared to the controls (Table 5), 5.6 and $2.8 \mu \mathrm{mol}$ of $\mathrm{CO}_{2} \mathrm{~m}^{-2} \mathrm{~s}^{-1}$, respectively. There was also no significant ER differences between the OTC's and control plots $(\mathrm{P}<0.18$, Figure 7).

Average net ecosystem exchange (NEE) varied significantly between the warming treatments (Table 4). OTC's and control had similar average rates of NEE (2.33 and $2.8358 \mu \mathrm{mol}$ of $\mathrm{CO}_{2} \mathrm{~m}^{-2} \mathrm{~s}^{-1}$, respectively), while the lamps had significantly greater NEE $\left(\mathrm{P}<0.001\right.$, Table 4) rates $\left(8.42 \mu \mathrm{mol}\right.$ of $\left.\mathrm{CO}_{2} \mathrm{~m}^{-2} \mathrm{~s}^{-1}\right)$. Microtopography was not a significant factor, but there was a near significant affect with the interaction of microtopography and warming (Table $4, \mathrm{P}=0.07$ ).

In sharp contrast to chamber based gas flux measurements, Sphagnum biomass production was greatest in control plots and decreased significantly with both warming treatments (Figure 8 \& Table 6). This was mostly caused by decreased biomass production in the hummocks (Figure 9). In the lawns there was no significant difference with warming, but the biomass accumulation was lower compared to the hummocks (Figure 10).

Volumetric water content at $12 \mathrm{~cm}$ depth was lower in hummocks than in lawns indicating the importance of the water table depth on Sphagnum moss photosynthesis (Figure $11 \& 12$ ). Water content was related to Sphagnum NEE in lawns (Figure 13). Warming did not have an effect on Sphagnum moss moisture content. Highest vapor pressure deficit of the leaf (VpdL) occurred at August, early September (Figure 14). Simultaneously with high VpdL and low amount of precipitation, Sphagnum NEE ceased in most study plots and was especially visible in hummocks (Figure 15). 


\section{Discussion}

\section{Vascular plants}

The two vascular plants in our study responded differently to experimental warming. Our results were contradictory to our hypothesis that vascular plants should increase their $\mathrm{CO}_{2}$ uptake. We found no difference in sedge $\mathrm{CO}_{2}$ uptake between warmed and control treatments, while the rate of $\mathrm{CO}_{2}$ uptake of leatherleaf dropped under both of our warming treatments independent of microtopography.

Our results are similar to those of (Weltzin et al. 2000), who found that Carex limosa, C. lasiocarpa and C. livida production was unaffected by IR warming in a fen mesocosm study in Minnesota, USA. Sullivan et al. (2008) also found that leaf length growth and $\mathrm{CO}_{2}$ uptake of Carex bigelowii did not change with OTC warming in a high arctic sedge fen in Greenland. However, long-term ( 25 yrs.) study in the Arctic found that increased temperatures increased Carex aquatilis and Carex membranacea above- and belowground biomass (Hill and Henry 2011).

Contrary to our finding, bog monolith mesocosms treated with IR lamp warming showed no difference in leatherleaf aboveground NPP (Weltzin et al. 2000). In addition, OTC warming in the high arctic significantly increased stem growth of shrub Salix arctica in hummocks (Sullivan et al. 2008). Although most of the increased growth was invested above ground through a doubling of stem length growth and probably increased leaf area, increases in root growth was also measured (Sullivan et al. 2008). Simultaneous increase in shrub Betula nana height growth with increased Sphagnum growth has been observed in OTC warming treatments (Dorrepaal et al. 2006).

These studies indicate that the physiology of these sedge species was not affected by warming and at higher temperatures they may not take up more carbon. Since the Pequaming field site is a poor fen, there are relatively few sedges and the amount of 
available nutrients and competition pressure might have limited sedge response to warming. That might be the reason why our initial hypothesis proved to be incorrect. Similarly, Carex oligosperma aboveground primary productivity in bog community did not respond to IR lamp warming (Weltzin et al. 2000). Sedges have been shown to have high growth rates and are influenced by nutrient addition (Aerts et al. 2006). Short-term warming manipulations do not increase nutrient availability since there is time lag of over 3 years between the initiation of a warming experiment and ecosystem response in nutrient availability (Chapin et al. 1995). An experiment in Alaskan sedge meadows showed that biomass production did not respond to short-term changes in temperature (Rydin and Jeglum 2006). However, a long-term (25 yrs.) warming study in Arctic measured an increase in $C$. aquatilis and $C$. membranacea above- and belowground biomass (Hill and Henry 2011). This increase probably was due to increased decomposition and mineralization in soil (Hill and Henry 2011). Because of the competition pressure and nutrient deficiency in our study, sedges may not have been able to take up more $\mathrm{CO}_{2}$ even if the temperature increase would be beneficial for sedge growth.

Our finding of a decline in leatherleaf $\mathrm{CO}_{2}$ uptake could be related to drier than average growing season and low water table levels. Shrub aboveground NPP seems to be related to site wetness; bogs and poor fens have much higher shrub NPP than rich fens (Szumigalski and Bayley 1997). During the growing season, the water table gradually declined to $25 \mathrm{~cm}$ below the surface. Low water table resulted in lower stomatal conductance. Stomatal conductance is directly linked to the photosynthesis since plants need to keep the stomata open in order to photosynthesize (Lambers et al. 1998). At the same time, we did not find significant differences in stomatal conductivity nor Vpd of the leaf between the warming treatments. Therefore, we cannot confirm why $\mathrm{CO}_{2}$ uptake decreased. One possible reason is that decreased $\mathrm{N}$ content in leaf due to decreased $\mathrm{N}$ availability in the soil. Leaf $\mathrm{N}$ content is vital for photosynthesis since more than $50 \%$ of the $\mathrm{N}$ in plant appears in leafs photosynthetic apparatus, especially in enzyme Rubisco which drives photosynthesis (Lambers et al. 1998). Leatherleaf is probably not at the 
thermal limit in the region since it can be found in much southerly locations (Myneni et al. 1997).

\section{Sphagnum gas exchange}

The limited amount of studies focusing on $\mathrm{CO}_{2}$ uptake of Sphagnum have generally been community scale responses to temperature where Sphagnum has been the dominant plant species (Silvola et al. 1996; Sullivan et al. 2008; Updegraff et al. 2001). We hypothesized that increased temperatures would reduce Sphagnum $\mathrm{CO}_{2}$ uptake but the opposite was observed with IR lamps. OTC warming resulted in no change at Sphagnum $\mathrm{CO}_{2}$ uptake compared to control plots, which means that our third hypothesis proved to be true. In our study, IR lamp warming increased NEE, ER and GEP of plots covered only by Sphagnum spp. Increase in NEE exhibits positive effect of temperature on Sphagnum photosynthesis. This might indicate that Sphagnum is not at its thermal limit and might be able to photosynthesize faster at higher temperatures. There was also a simultaneous increase in both ER and GEP. ER is dependent on water table position and temperature (Moore et al. 1998; Updegraff et al. 2001). In our case ER rose significantly under IR lamps, which had much higher soil warming than the OTC's. The IR lamps raised the average soil temperatures by $1.4^{\circ} \mathrm{C}$ while OTC's had similar soil temperatures compared to control plots (Chris Johnson, unpublished data). Similarly, Updegraff et al. (2001) observed an increase in ER in both bog and fen plant communities under IR lamp warming while the water table depth had no significant influence (Updegraff et al. 2001). In our study, the water table depth stayed in upper $25 \mathrm{~cm}$ for most of the growing season and IR lamp warming had positive effect on ER compared to control, which resulted in a $100 \%$ increase. Since we did not modify water table levels between treatments, we can conclude that IR lamp warming increased ER in our study.

In nutrient poor ecosystems, like boreal peatlands, warming has been found to enhance ER (Chapin 1983). Summarized findings from different ecosystems indicate exponential relationship between temperature and ER (Lloyd and Taylor 1994). Increase in ER indicates the increase either in plant biomass, and therefore plant respiration, or an 
increase in soil respiration (Sullivan et al. 2008). Both plant production and ER are positively influenced by temperature, but ER increases more in short time scale warming treatments (Woodwell 1995). $\mathrm{CO}_{2}$ fluxes from soils were found to be influenced by temperature much more if the water table is $0-20 \mathrm{~cm}$ beneath the surface compared to lower water tables $\left(\mathrm{Q}_{10}\right.$ value of 4.9 and 1.3, respectively)(Weltzin et al. 2001). The same temperature effect for water table depths of $0-20 \mathrm{~cm}\left(\mathrm{Q}_{10}\right.$ value being 2.9) has been shown by (Silvola et al. 1996). Temperature and water table level play significant role in carbon cycling of boreal peatlands. $\mathrm{CO}_{2}$ fluxes from boreal peatlands have shown to rise up to 10 times if you compare fluxes under $10^{\circ} \mathrm{C}$ with high water table levels and summertime $\mathrm{CO}_{2}$ fluxes with lowered water table (Silvola et al. 1996). Summer ER might be higher than $\mathrm{CO}_{2}$ uptake of bog plant community, resulting in negative NEE (Alm et al. 1999; Moore et al. 2002). At present, peatlands can be sources for $\mathrm{CO}_{2}$ at current summer temperatures (Burrows 2005). Drier than average summers resulted in water table level $15 \mathrm{~cm}$ below surface which resulted in increased ER which exceeded NPP in study by Alm et al. (1999). This all indicates that during the summer, when water table levels drop and peat is exposed to aeration, ER increases due to higher temperatures and could be even higher than $\mathrm{CO}_{2}$ uptake by vegetation.

\section{Sphagnum NPP}

Our seasonal Sphagnum NPP measurements were contradictory to our daytime gas flux measurements. Increased $\mathrm{CO}_{2}$ uptake by Sphagnum should increase seasonal NPP, but the opposite was observed. While this reduction was evident in both hummocks and lawns, it was significantly greater only in hummocks where S. fuscum was dominant. This indicates that while Sphagnum is able to take up more $\mathrm{CO}_{2}$ at higher temperatures, it is vulnerable to moisture availability. Our results are contradictory to studies where summer warming increased Sphagnum growth (Dorrepaal et al. 2004; Dorrepaal et al. 2006; Sonesson et al. 2002). OTC warming in northern Sweden increased S. fuscum summer length increment by 62 and $42 \%$ in two consecutive years after the warming 
treatment was set up (Dorrepaal et al. 2004). Even though the warming also reduced bulk density of Sphagnum, the biomass accumulation increased. Also Sonesson et al. (2002) found increased S. fuscum length increment in warming treatments. When combined with additional precipitation of $1 \mathrm{~mm}$ per day, the length increment rose by $50 \%$ in spring and $33 \%$ in peak growing season. However, IR lamp warming of boreal peatland mesocosms did not increase Sphagnum production in Minnesota (Weltzin et al. 2001).

Our observed reduction in Sphagnum NPP might be due to water stress since Sphagnum production is highly water dependent (Titus et al. 1983; Weltzin et al. 2001). Our observed reduction in NPP was greater in hummocks, which are even further away from the water table. The summer of 2010 had less than average amount of precipitation, especially in July and August. Vapor pressure deficit of the leaf was significantly higher in August and early September compared to July or October (Figure 14). During the growing season, the water table fell gradually, reaching a minimum of $25 \mathrm{~cm}$ below the lawn surface by the end of August. During measurement days in August, the Sphagnum photosynthesis was decreased at most study plots since the capitulum was dry and had a bleached color (Figure 15). Just before the next measurement (September 2010), there was a small precipitation event $(2.5 \mathrm{~mm})$ in the morning, which allowed photosynthesis to recover. Small precipitation events less than $5 \mathrm{~mm}$ have the same effect on capitulum moisture content as a rise in water table level of $20 \mathrm{~cm}$, and has major implications on photosynthesis (Strack and Price 2009). These small events moisten the capitulum and therefore have big implications on photosynthesis since Sphagnum does not possess roots. Water is essential in maintaining photosynthetic capacity for Sphagnum and water lost in evaporation must be replaced from water table (Schipperges and Rydin 1998). Height of the water table determines the Sphagnum capitulum moisture content; moisture content decreases with decreasing water table levels (Titus et al. 1983). We found that NEE was influenced by the moisture content at $12 \mathrm{~cm}$ depth in lawns (Figure 13).

Volumetric water content in upper $10 \mathrm{~cm}$ of soil is dependent of the water table depth in upper $55 \mathrm{~cm}$ of peat (Strack and Price 2009). Sphagnum abundance has shown to 
decline if water table levels are lower than $50 \mathrm{~cm}$ beneath the surface (Moore et al. 2002). Lower water table resulted in 50-80\% reduction of Sphagnum NPP between two years of measurements (Szumigalski and Bayley 1997). Additionally, S. fuscum growth has been shown to be highest when water table is $0-10 \mathrm{~cm}$ below the capitulum (Jauhiainen et al. 1997). In our study the water table level fell as low as $25 \mathrm{~cm}$ beneath the surface while Sphagnum fuscum, the dominant Sphagnum species on hummocks where the reduction in NPP was significant, was elevated even further away from the water table. Sphagnum production seems to be correlated to the height of the water table since low microtopography has $100 \%$ higher NPP values than high microtopography (Weltzin et al. 2001). Similarly in the same study, warming did not increase Sphagnum production, instead it was more influenced by the water table. In Alaska, optimum water content for photosynthesis for Sphagnum mosses was 6-10 times the dry weight, below that the photosynthesis starts to decrease (Murray et al. 1989). If Sphagnum capitulum is dry for extended periods, growth has been found to be reduced (Schipperges and Rydin 1998). Desiccation experiments showed that Sphagnum is able to recover to some extent from short desiccation periods, but is not able to recover after 12 days of desiccation (Schipperges and Rydin 1998). Because of the low water table level and high VpdL from August to September, the reduction in NPP might have occurred between the measurement days. Both warming treatments might have increased canopy temperatures and therefore higher evapotranspiration compared to control plots making water even less available for photosynthesis.

Another aspect which could have influenced the reduction of Sphagnum NPP in our study is an increase in nighttime plant respiration. Like all biological processes, plant and soil respiration increases with higher temperatures (Woodwell and Whittaker 1968). During the nighttime when no photosynthesis occurs, it can result in greater $\mathrm{CO}_{2}$ losses compared to nights with lower soil temperatures. Nighttime soil respiration has been linked to temperatures at $5 \mathrm{~cm}$ depth (Goulden and Crill 1997) and areas with greater plant cover have been shown to lose more $\mathrm{CO}_{2}$ at night, indicating the role of root respiration in nighttime soil respiration (Billings 1987). 


\section{Conclusions}

Neither of the vascular plants increased $\mathrm{CO}_{2}$ uptake under warming, which is contrary to our hypothesis. We expected that short term warming would increase vascular plant photosynthesis, while long-term warming would cause nutrient limitations and inhibit photosynthesis (Shaver et al. 2000). It is possible that the low nutrient status of our site might have influenced the non-responsiveness of sedges to warming. Leatherleaf decreased its $\mathrm{CO}_{2}$ uptake at higher temperatures which again is against our hypothesis. Low water table level might play a role here since water table is able to influence stomatal conductance of leatherleaf. But we still could not find any evidence behind the drop in leatherleaf $\mathrm{CO}_{2}$ uptake. Our hypothesis that Sphagnum 's $\mathrm{CO}_{2}$ uptake will drop turned out to be disproven as Sphagnum was able to increase its $\mathrm{CO}_{2}$ uptake under IR lamp warming, while this increase in $\mathrm{CO}_{2}$ uptake seems to be dependent on moisture availability. However, Sphagnum NPP decreased. Current climatic predictions indicate that precipitation in northern latitudes will increase (IPCC 2007), however most of the precipitation increase will probably happen during the wintertime (Dorrepaal et al. 2004; Houghton 2005; Prentice et al. 1991). Our results indicate the importance of summer precipitation to Sphagnum biomass accumulation. Sphagnum has shown to gain competitive advantage over Dicranum elongatum in natural mixtures of these two species if both temperature and precipitation increase (Sonesson et al. 2002). Since higher temperatures are able to increase evapotranspiration (Gignac and Vitt 1994; Mitchell 1989), summertime water table height and precipitation events become even more important. Our study demonstrates that Sphagnum is not at its thermal limit in sub-boreal

climatic zone but future summertime precipitation amounts and patterns will determine its vitality in this ecosystem. 


\section{Tables}

Table 1.

Average percent (\%) cover of plant species by treatment and microtopography. Sphagnum and vascular plants are divided into two vegetation layers, each summing up to $100 \%$

\begin{tabular}{|c|c|c|c|c|c|c|}
\hline \multirow[b]{2}{*}{ Species } & \multicolumn{3}{|l|}{ Hummock } & \multicolumn{3}{|l|}{ Lawn } \\
\hline & Control & OTC & Lamp & Control & OTC & Lamp \\
\hline Picea mariana & $32 \%$ & $2 \%$ & $7 \%$ & & & \\
\hline Chamaedaphne calyculata & $19 \%$ & $27 \%$ & $37 \%$ & $6 \%$ & $1 \%$ & $22 \%$ \\
\hline Vaccinium oxycoccos & $19 \%$ & $17 \%$ & $24 \%$ & $28 \%$ & $31 \%$ & $22 \%$ \\
\hline Carex exilis & $8 \%$ & & & $21 \%$ & $13 \%$ & $20 \%$ \\
\hline Carex oligosperma & $4 \%$ & & $3 \%$ & $17 \%$ & $13 \%$ & $18 \%$ \\
\hline Ledum groenlandicum & $4 \%$ & $5 \%$ & $6 \%$ & & & $1 \%$ \\
\hline Kalmia polifolia & $4 \%$ & $13 \%$ & $8 \%$ & $8 \%$ & $19 \%$ & $7 \%$ \\
\hline Andromeda polifolia & $3 \%$ & $17 \%$ & $4 \%$ & $8 \%$ & $10 \%$ & $4 \%$ \\
\hline Myrica gale & $3 \%$ & $12 \%$ & & $6 \%$ & $3 \%$ & $2 \%$ \\
\hline Sarracenia purpurea & $1 \%$ & & & $2 \%$ & & $1 \%$ \\
\hline Drosera rotundifolia & $1 \%$ & & $4 \%$ & & $9 \%$ & $2 \%$ \\
\hline Larix laricina & $1 \%$ & $4 \%$ & & & & \\
\hline Carex utriculata & $1 \%$ & $3 \%$ & $1 \%$ & $4 \%$ & $1 \%$ & $1 \%$ \\
\hline Carex pauciflora & & & $6 \%$ & & & \\
\hline Sphagnum fuscum & $59 \%$ & $30 \%$ & $82 \%$ & $1 \%$ & & \\
\hline Sphagnum rubellum & $27 \%$ & $7 \%$ & $5 \%$ & $63 \%$ & $57 \%$ & $62 \%$ \\
\hline Sphagnum magellanicum & $10 \%$ & $60 \%$ & $13 \%$ & $1 \%$ & & $12 \%$ \\
\hline Sphagnum papillosum & $4 \%$ & $1 \%$ & & $17 \%$ & $43 \%$ & $26 \%$ \\
\hline Sphagnum angustifolium & & $1 \%$ & & $18 \%$ & & \\
\hline Sphagnum capillifolium & & $1 \%$ & & & & \\
\hline
\end{tabular}


Table 2.

ANOVA results for Leatherleaf $\mathrm{CO}_{2}$ uptake

\begin{tabular}{llllll}
\hline Source & Sum-of-Squares & df & Mean-Square & F-ratio & P \\
\hline Topography & 0.546 & 1 & 0.546 & 0.045 & 0.83 \\
Warming & 74.356 & 2 & 37.178 & 3.091 & $<0.05$ \\
Warming*Topography & 1.250 & 2 & 0.625 & 0.052 & 0.95 \\
Error & 1443.365 & 120 & 12.028 & & \\
\hline
\end{tabular}


Table 3.

ANOVA results for Sedge $\mathrm{CO}_{2}$ uptake

\begin{tabular}{llllll}
\hline Source & Sum-of-Squares & df & Mean-Square & F-ratio & P \\
\hline Topography & 13.212 & 1 & 13.212 & 0.899 & 0.35 \\
Warming & 0.339 & 2 & 0.169 & 0.012 & 0.99 \\
Warming*Topography & 1.697 & 2 & 0.849 & 0.058 & 0.94 \\
Error & 1602.174 & 109 & 14.699 & & \\
\hline
\end{tabular}


Table 4.

ANOVA results for Sphagnum net ecosystem exchange (NEE)

\begin{tabular}{llllll}
\hline Source & Sum-of-Squares & df & Mean-Square & F-ratio & P \\
\hline Warming & 961.047 & 2 & 480.524 & 12.630 & $<0.01$ \\
Topography & 79.530 & 1 & 79.530 & 2.090 & 0.15 \\
Warming*Topography & 212.678 & 2 & 106.339 & 2.795 & 0.07 \\
Error & 4565.398 & 120 & 38.045 & & \\
\hline
\end{tabular}


Table 5.

ANOVA results for Sphagnum Ecosystem respiration (ER)

\begin{tabular}{llllll}
\hline Source & Sum-of-Squares & df & Mean-Square & F-ratio & P \\
\hline Warming & 292.101 & 2 & 146.051 & 12.065 & $<0.01$ \\
Topography & 13.731 & 1 & 13.731 & 1.134 & 0.29 \\
Warming*Topography & 7.842 & 2 & 3.921 & 0.324 & 0.72 \\
Error & 1452.593 & 120 & 12.105 & & \\
\hline
\end{tabular}


Table 6.

ANOVA results for mean Sphagnum biomass accumulation

\begin{tabular}{rrrrrr}
\hline Source & Sum-of-Squares & df & Mean-Square & F-ratio & P \\
Warming & 129499.7 & 2 & 64749.877 & 34.549 & $<0.01$ \\
Microtopography & 0.129 & 1 & 0.129 & 0.000 & 0.99 \\
Warming*Topography & 44124.5 & 2 & 22062.292 & 11.772 & $<0.01$ \\
Error & 1892897 & 101 & 1874.156 & & \\
\hline
\end{tabular}




\section{Figures}

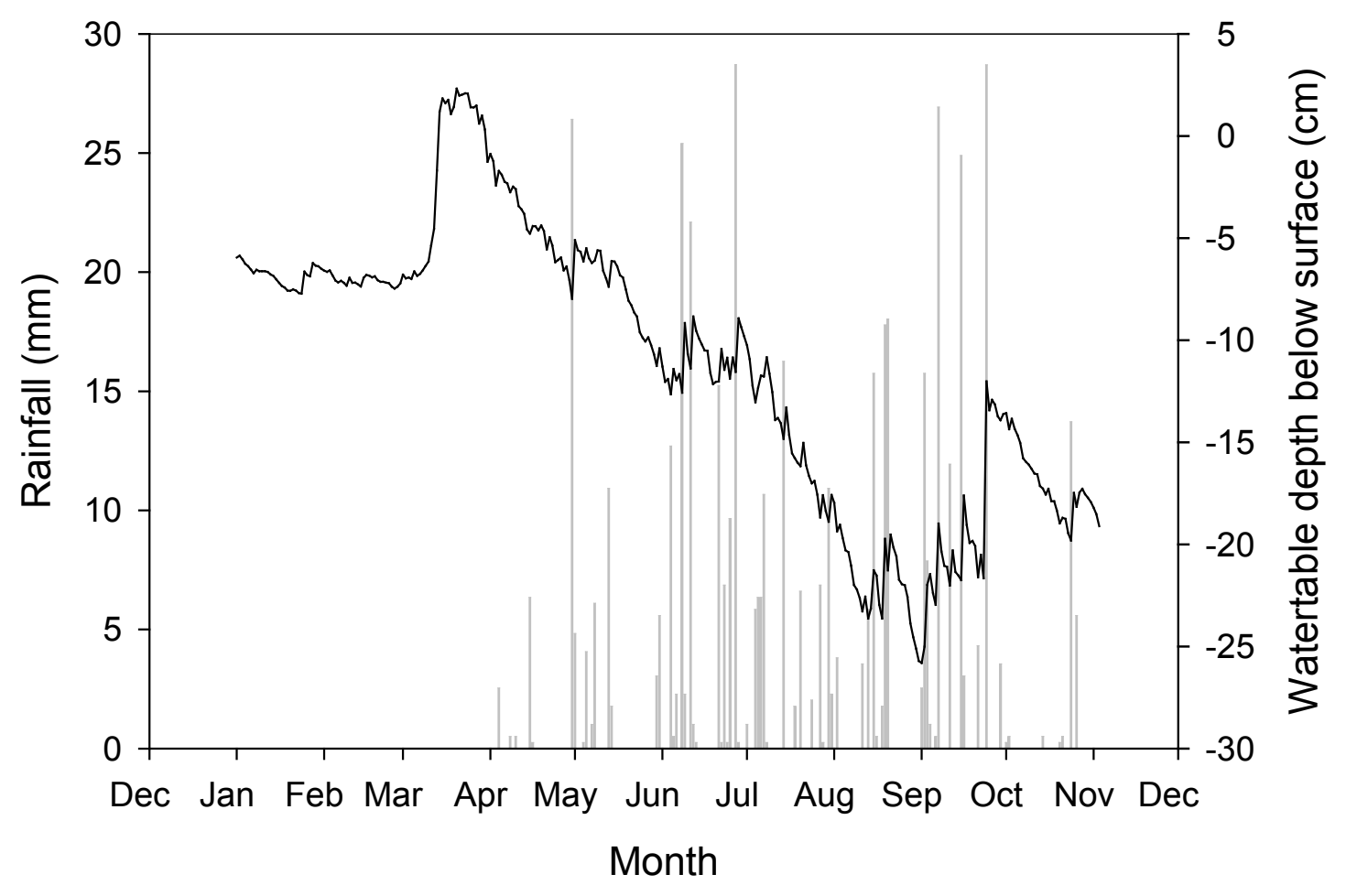

Figure 1. Water table depth and precipitation amounts (study period only) at Pequaming during 2010. Water table depth marked as solid black line and precipitation as gray bars. 


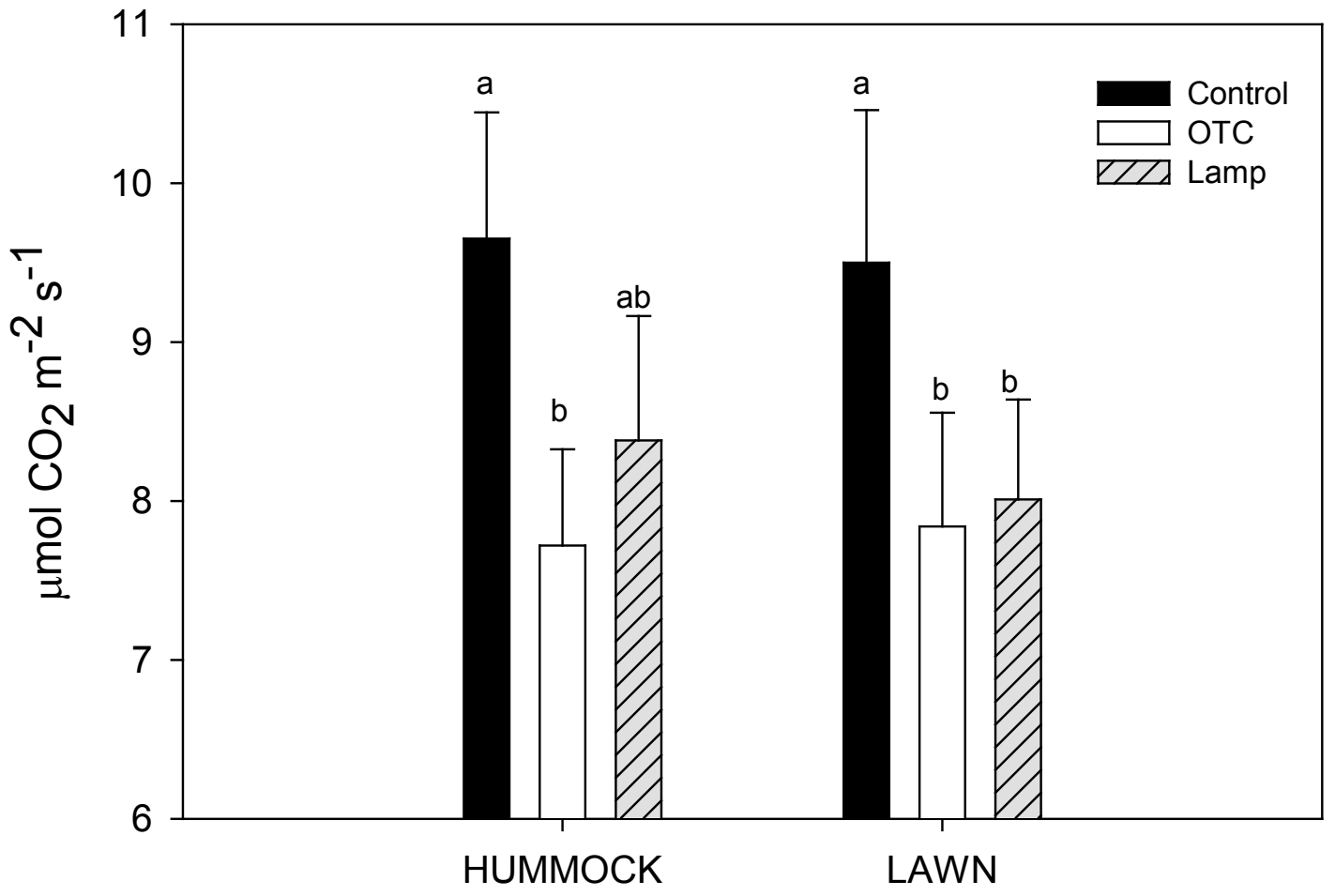

Figure 2. Average (se) $\mathrm{CO}_{2}$ uptake of Leatherleaf (Chamaedaphne calyculata) in two different microtopography features and two different warming treatments. Positive values indicate $\mathrm{CO}_{2}$ uptake by leatherleaf. 


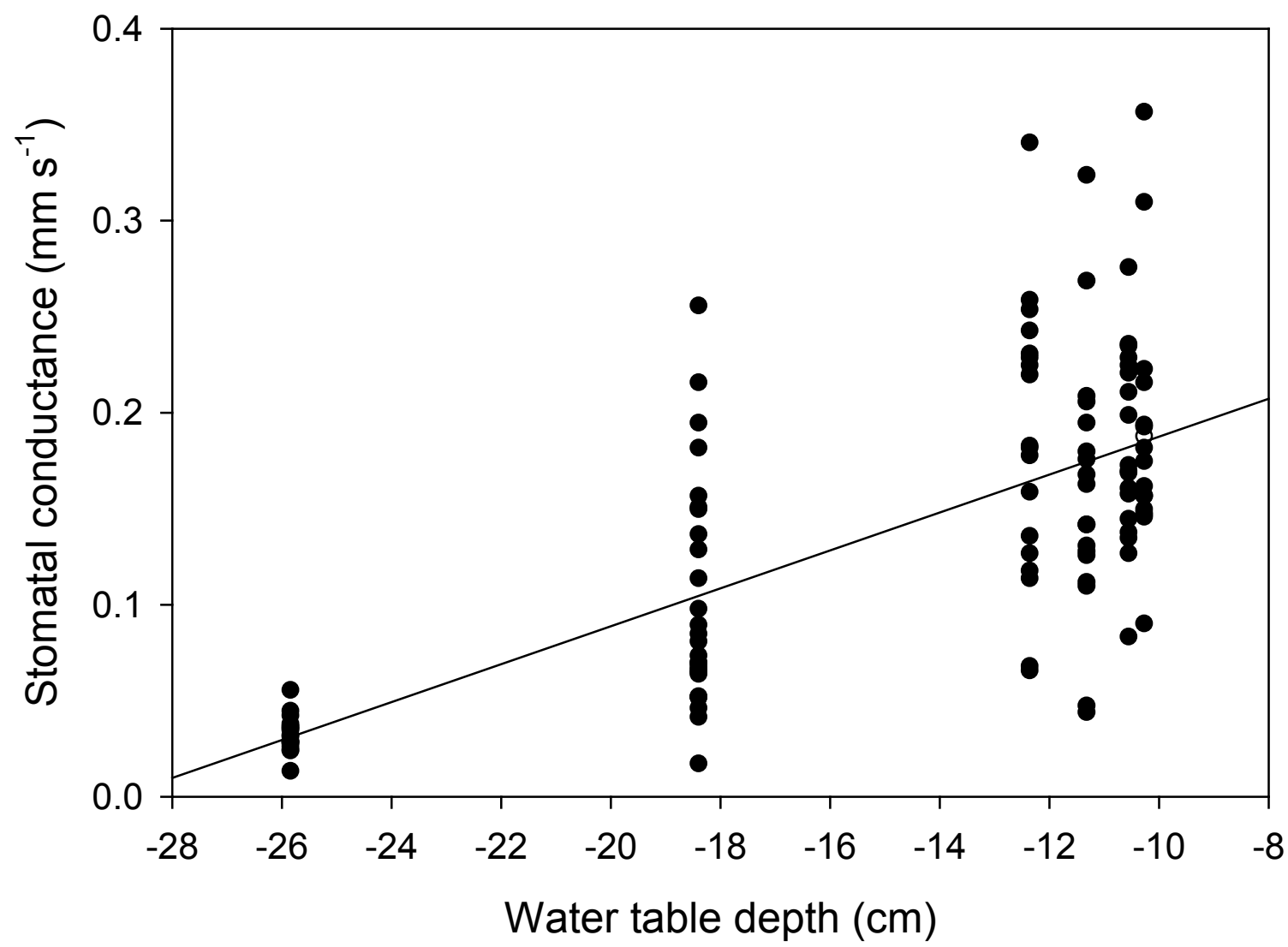

Figure 3. Correlation between water table depth $(\mathrm{cm})$ and leatherleaf stomatal conductance. Larger values of stomatal conductance indicate the openness of stomata. 


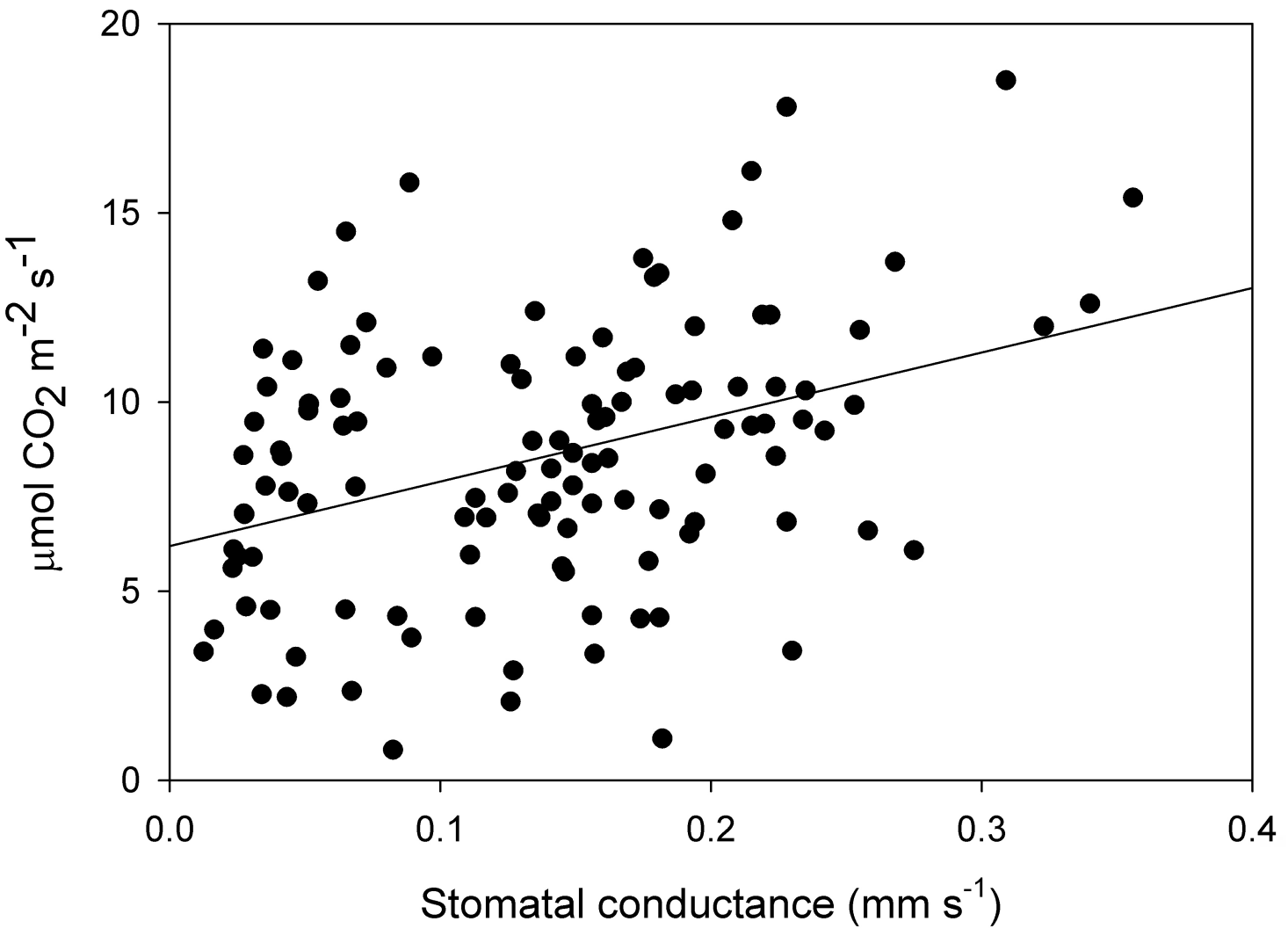

Figure 4. Correlation between leatherleaf stomatal conductance and $\mathrm{CO}_{2}$ uptake. 


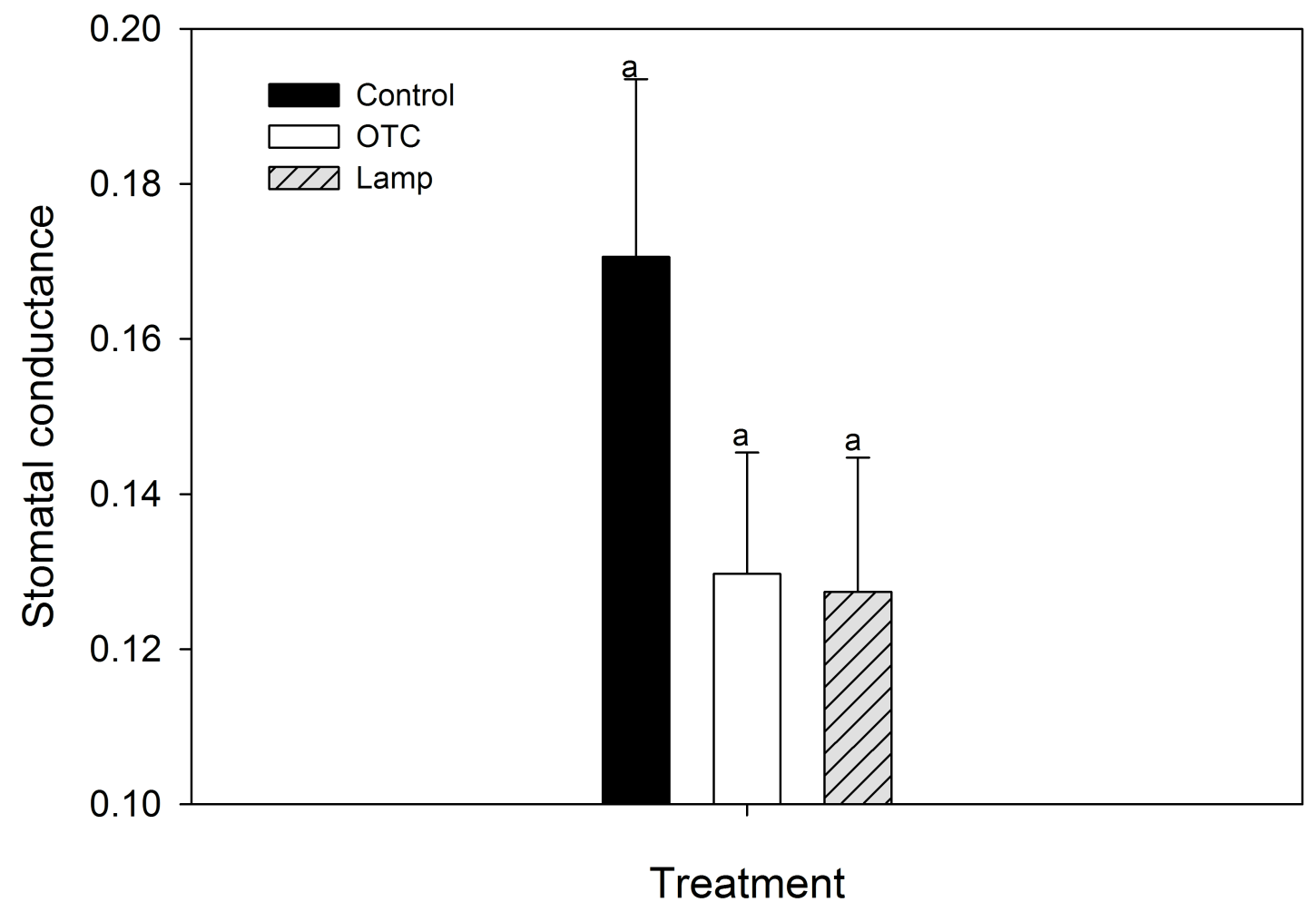

Figure 5. Average (se) warming treatment effect on stomatal conductance $\left(\mathrm{mmol} \mathrm{s}^{-1}\right)$ of leatherleaf in lawns. Larger values of stomatal conductance indicate openness of stomata. 


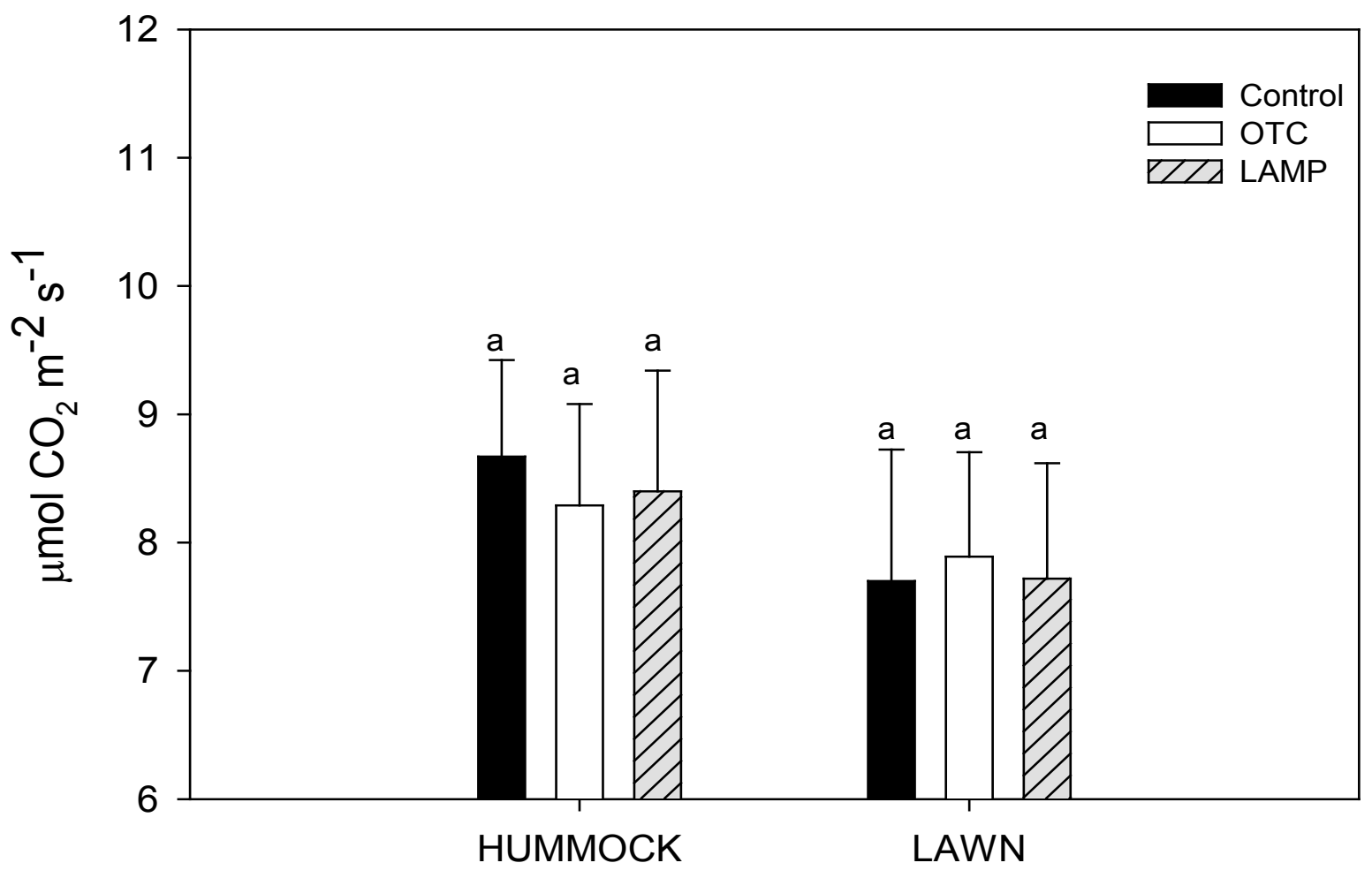

Figure 6. Average (se) $\mathrm{CO}_{2}$ uptake of Sedge (Carex utriculata) in two different microtopography features and two different warming treatments. Positive values indicate $\mathrm{CO}_{2}$ uptake by sedge. 


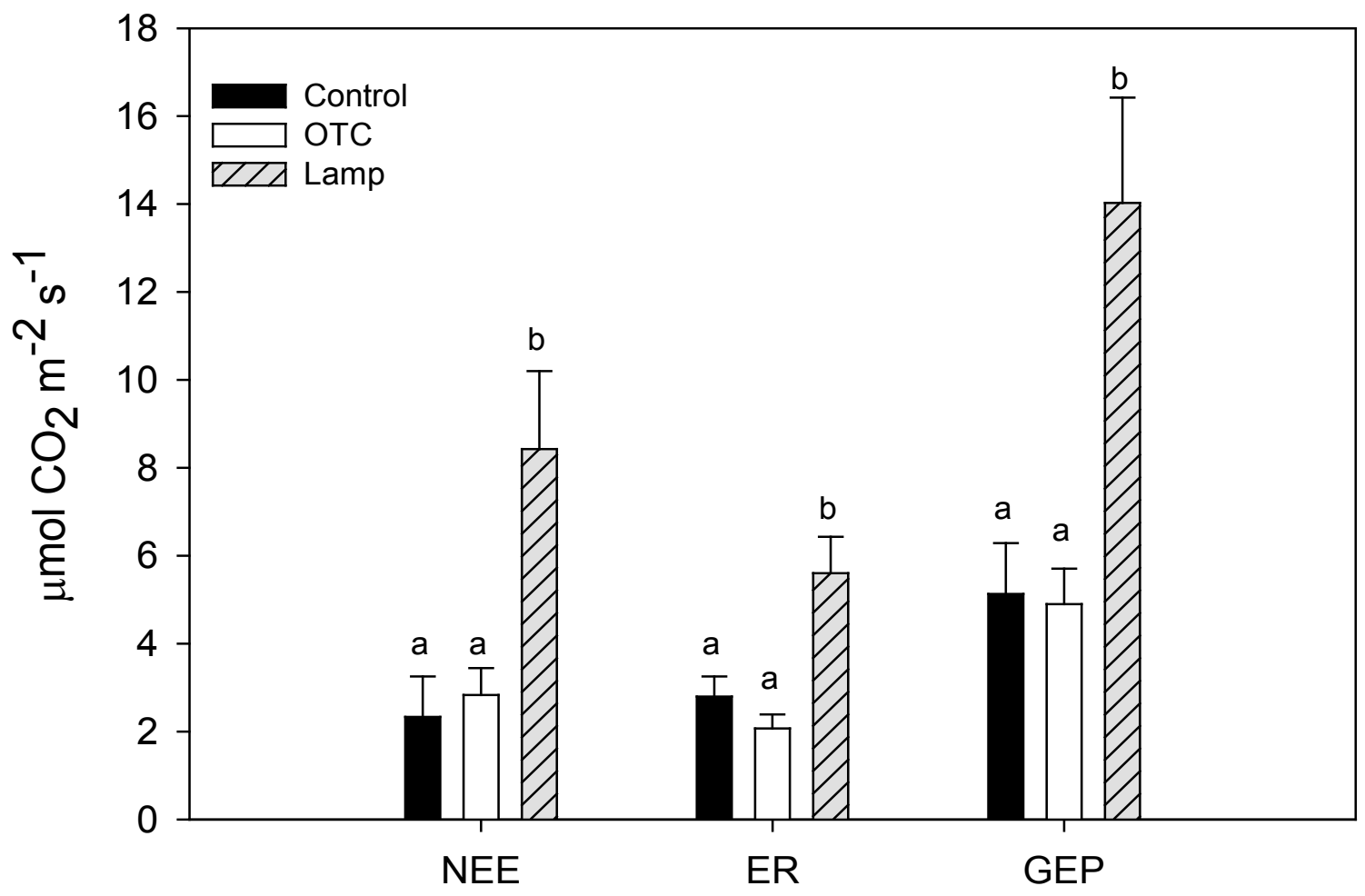

Figure 7. Average (se) $\mathrm{CO}_{2}$ exchange by Sphagnum moss over two different microtopography features and two different warming treatments. Positive values of NEE indicate the amount of $\mathrm{CO}_{2}$ taken up from the atmosphere and positive values of ER the amount of $\mathrm{CO}_{2}$ released to the atmosphere by Sphagnum . 


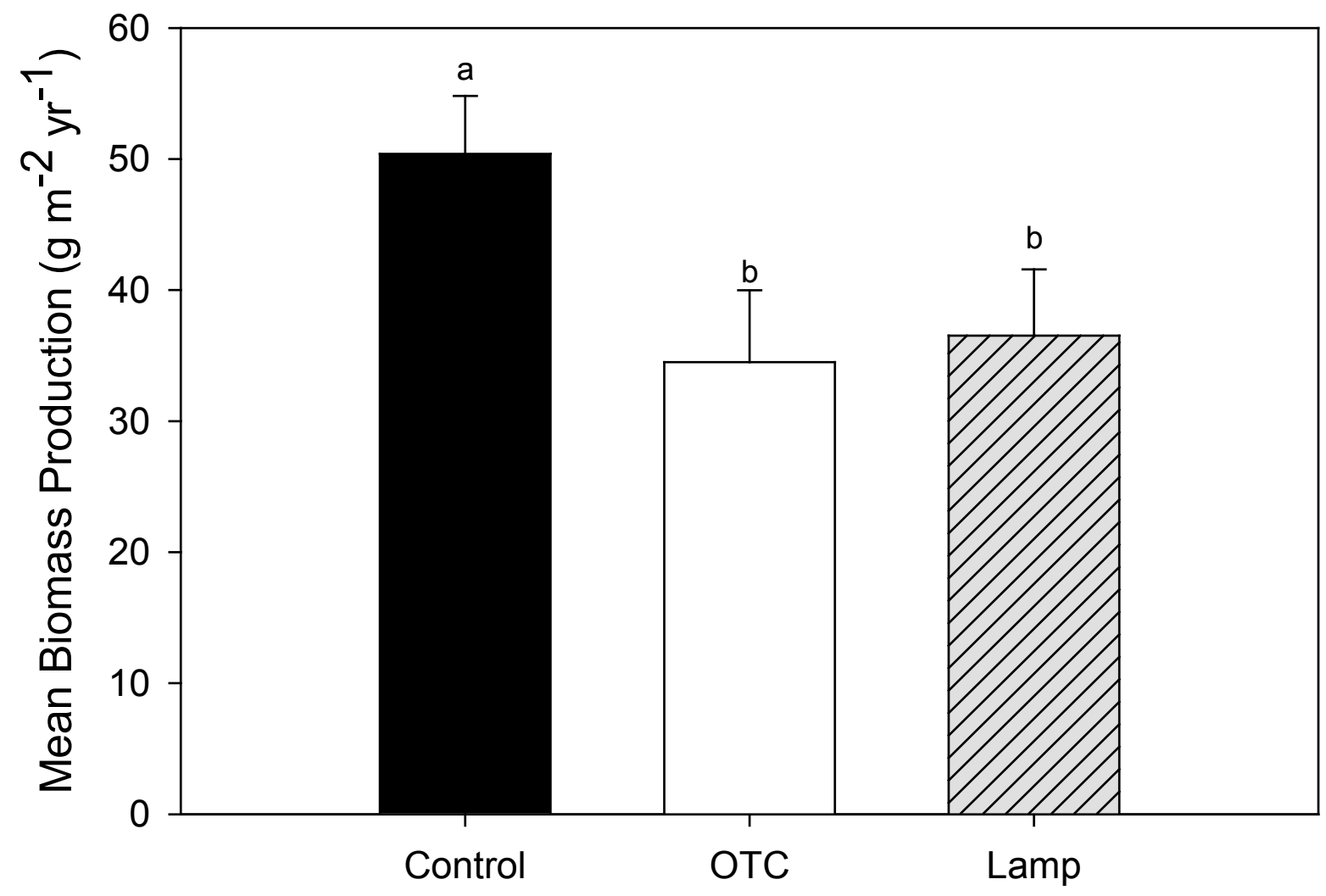

Figure 8. Mean (se) Sphagnum biomass accumulation from $30^{\text {th }}$ of May to $15^{\text {th }}$ of October 2010. 


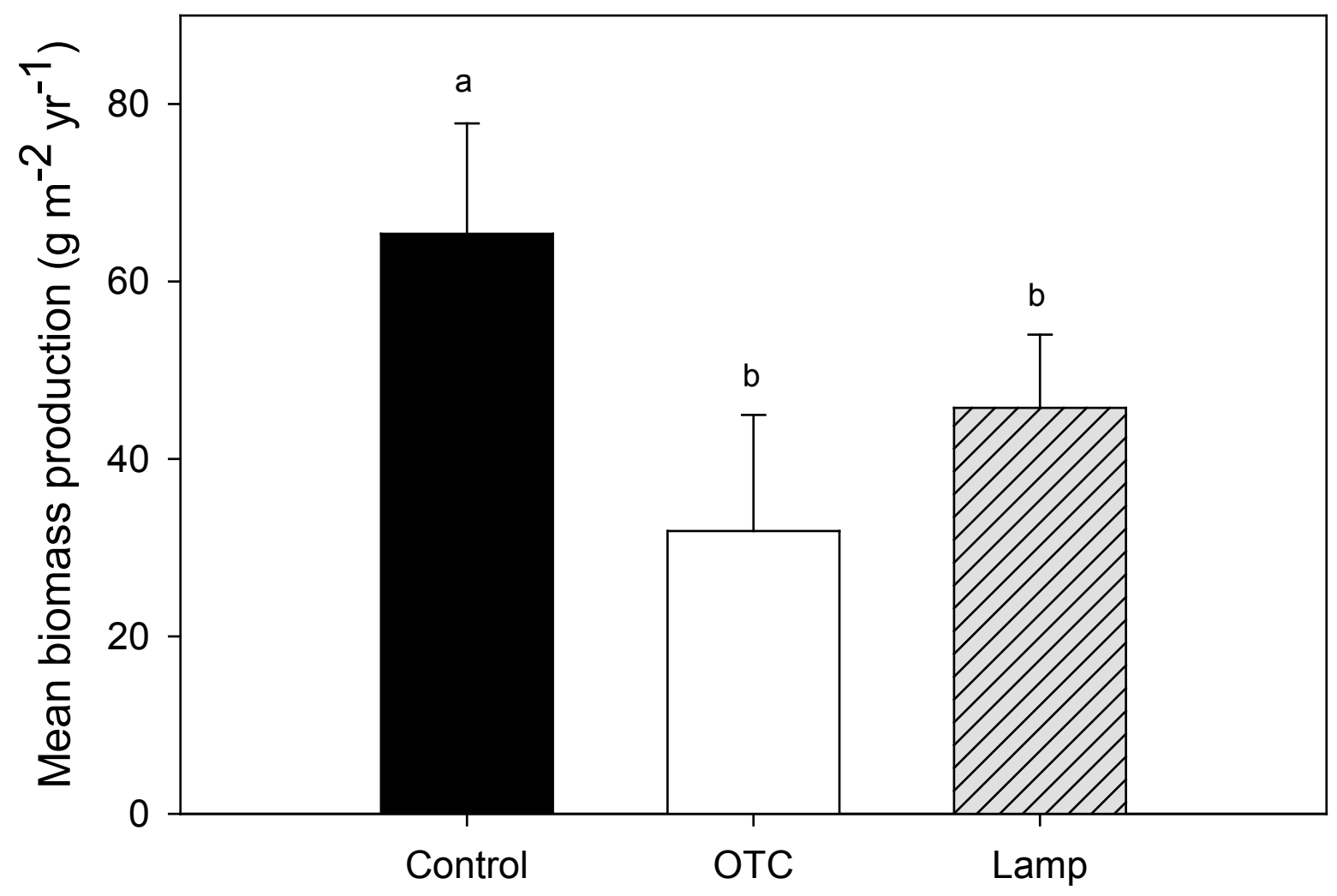

Figure 9. Mean (se) biomass production of Sphagnum moss on hummocks. 


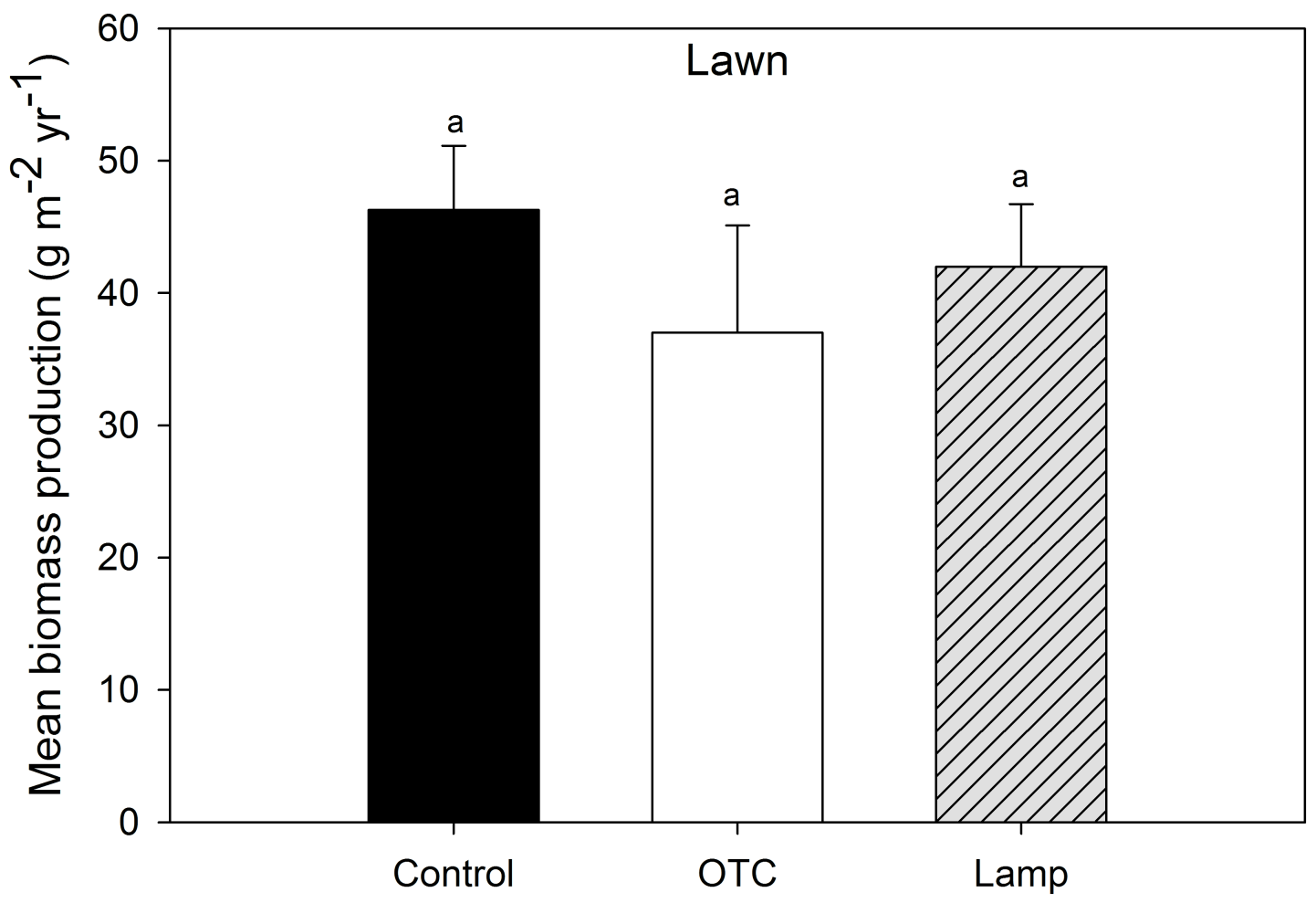

Figure 10. Mean (se) biomass production of Sphagnum moss on lawns. 


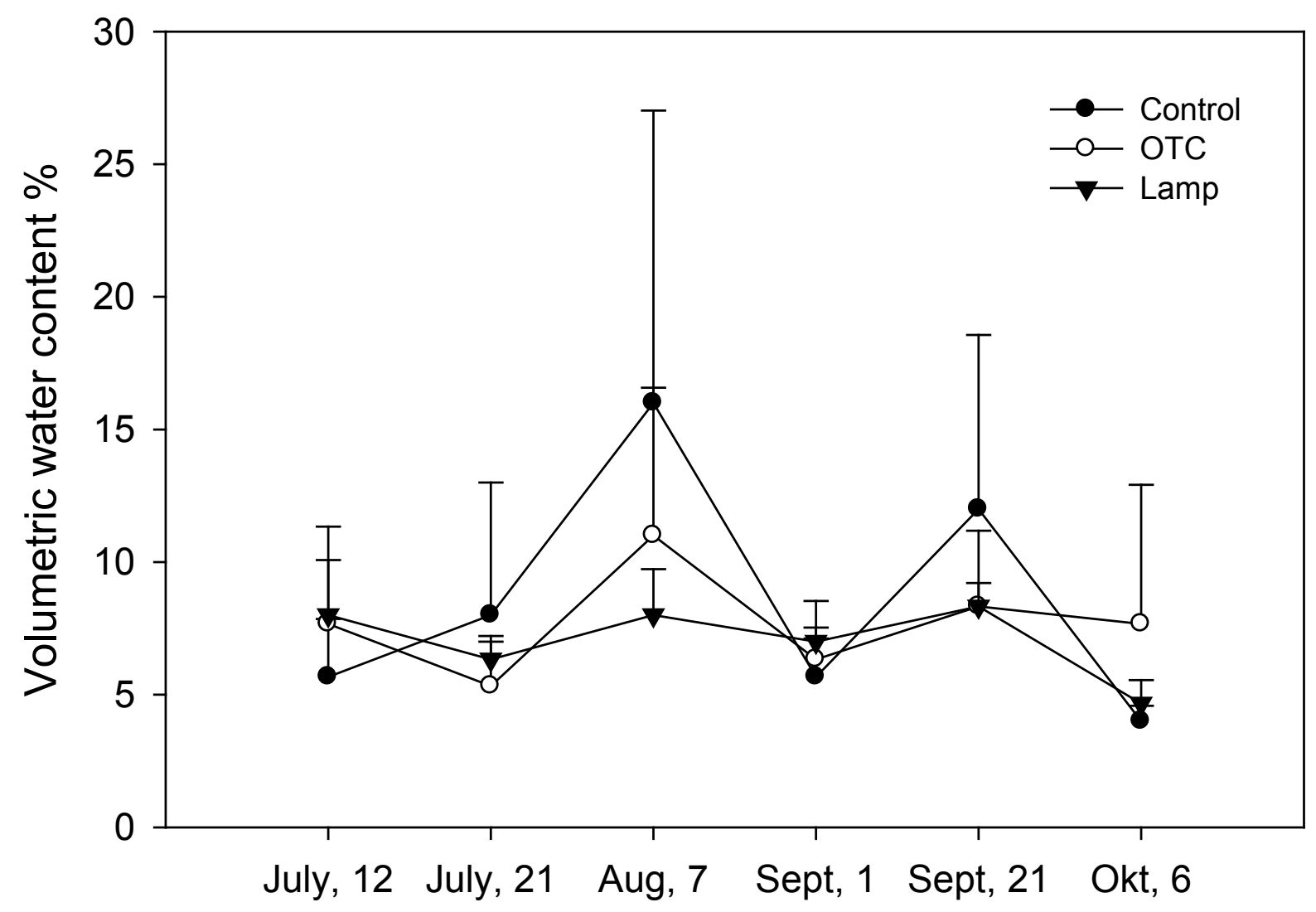

Figure 11. Average volumetric water content (se) of Sphagnum moss in hummocks, 12 $\mathrm{cm}$ beneath the surface. Lines help to clarify trends but do not indicate changes in volumetric water content between measurement days. 


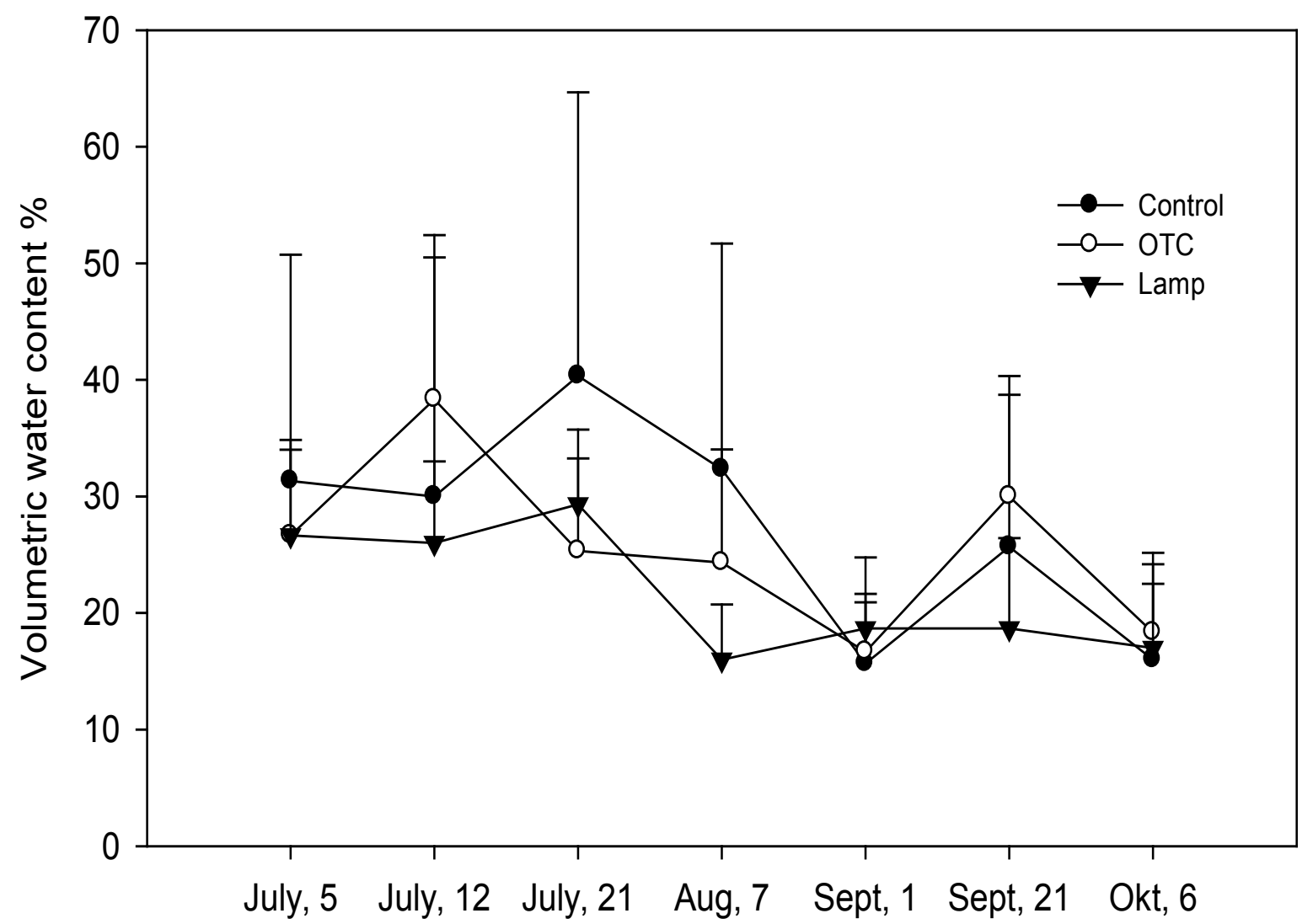

Figure 12. Average volumetric water content (se) of Sphagnum moss in lawns, $12 \mathrm{~cm}$ beneath the surface. Lines help to clarify trends but do not indicate changes in volumetric water content between measurement days. 


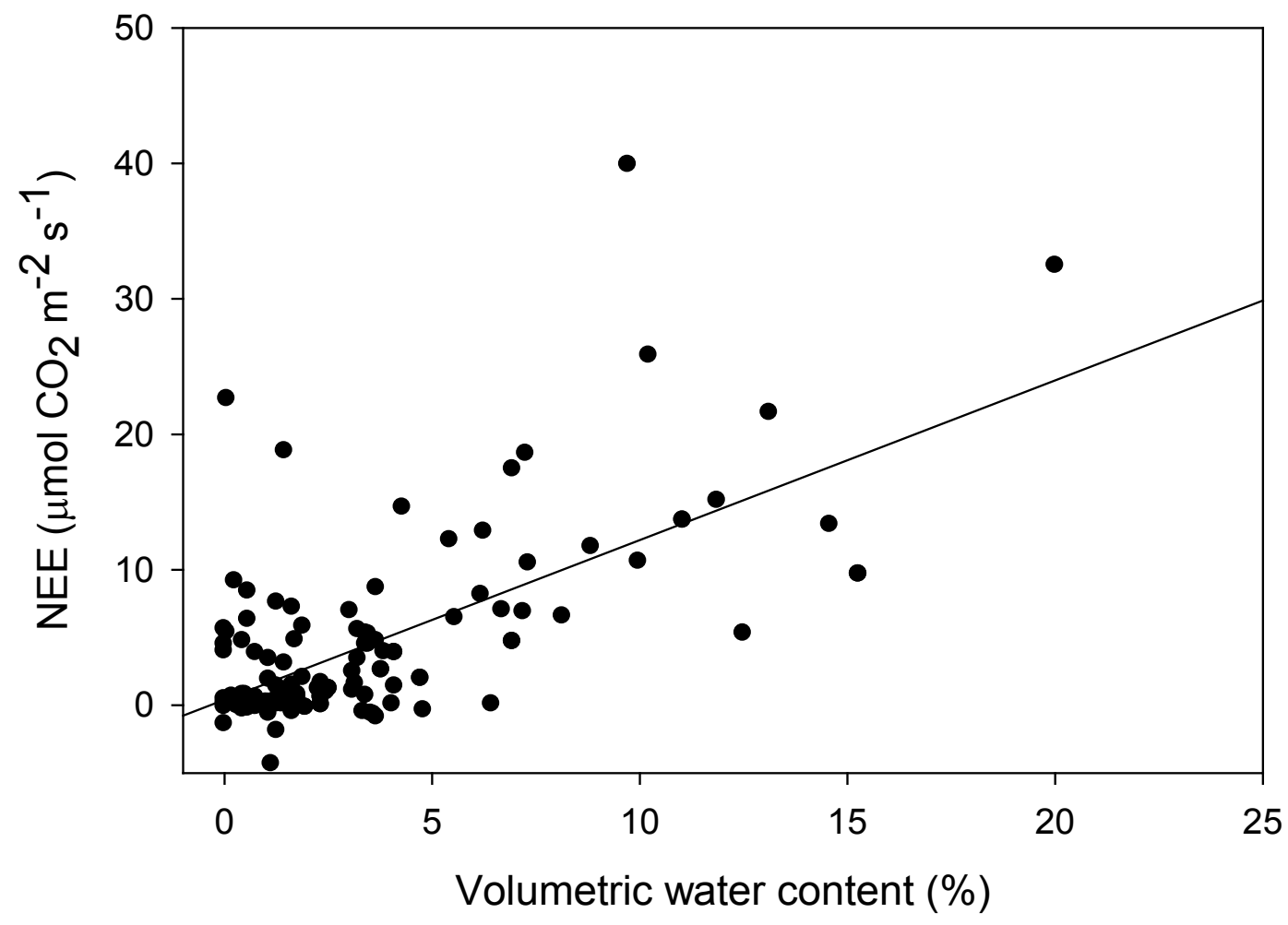

Figure 13. Correlation between volumetric water content $12 \mathrm{~cm}$ beneath the surface and Sphagnum NEE in lawns. 


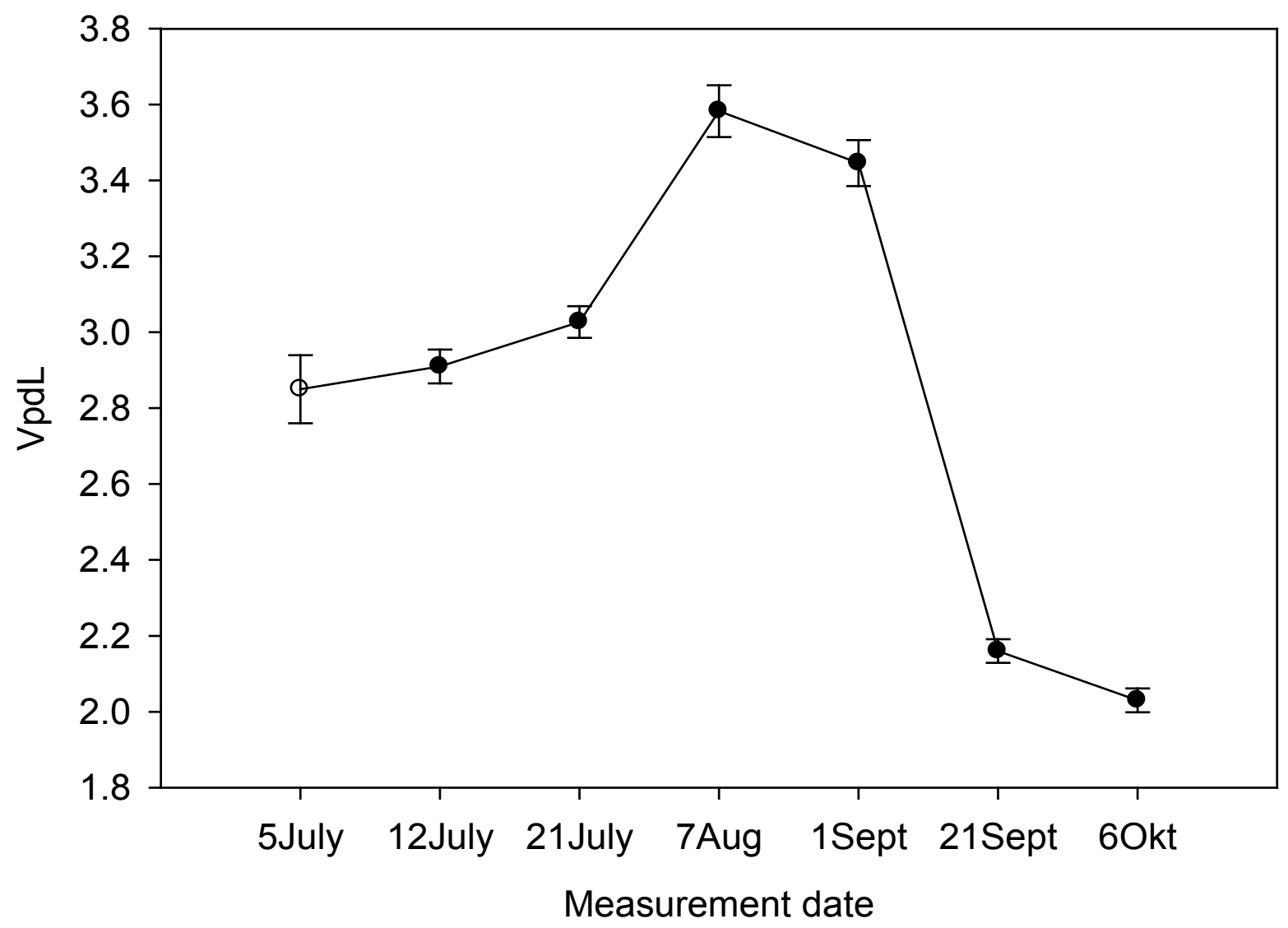

Figure 14. Sphagnum vapor pressure deficit (se) by date. 


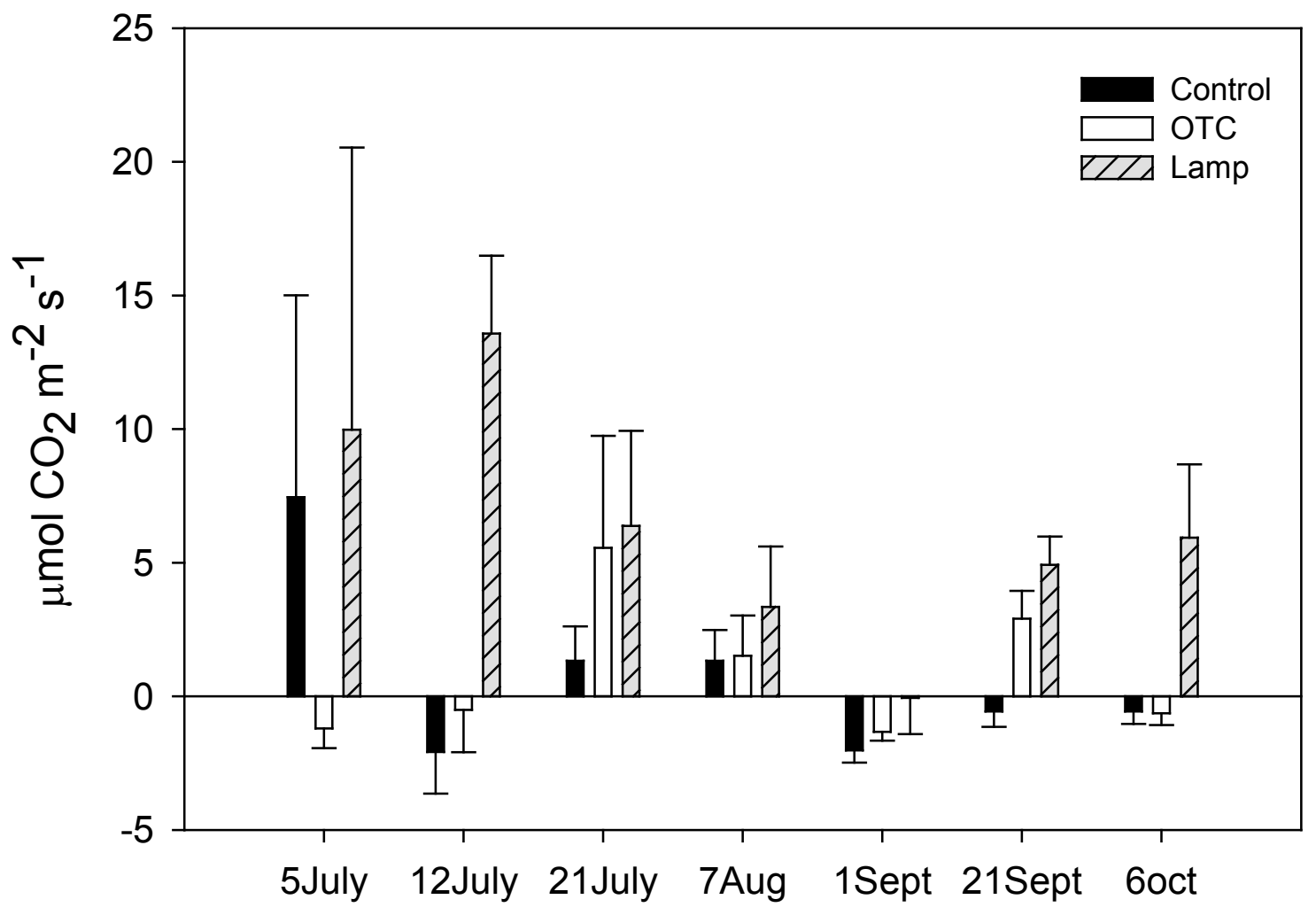

Figure 15. Sphagnum NEE (se) in hummocks by date. 


\section{References:}

Aber J, McDowell W, Nadelhoffer K, Magill A, Berntson G, Kamakea M, Fernandez I. 1998. Nitrogen saturation in temperate forest ecosystems - Hypotheses revisited. BioScience. 48(11): 921-934.

Aerts R, Cornelissen JHC, Dorrepaal E. 2006. Plant Performance in a Warmer World: General Responses of Plants from Cold, Northern Biomes and the Importance of Winter and Spring Events. Plant Ecology. 182(1/2): 63-77.

Aerts R, Wallen B, Malmer N. 1992. Growth-limiting nutrients in Sphagnum-dominated bogs subject to low and high atmospheric nitrogen supply. Journal of Ecology. 80(1): 131-140.

Aerts R, Verhoeven JTA, Whigham DF.1999. Plant-mediated controls on nutrient cycling in temperate fens and bogs. Ecology. 80(7): 2170-2181.

Albert DA. US Department of Agriculture, Forest Service, North Central Forest Experiment Station. 1995. Jamestown, (ND). Northern Prairie Wildlife Research Center Regional landscape ecosystems of Michigan, Minnesota, and Wisconsin: a working map and classification. General Technical Report NC-178. St. Paul, (MN); [updated 2008 Jun 03, cited 2010 Oct 10]. Available from: http://www.npwrc.usgs.gov/resource/habitat/rlandscp/index.htm

Allison SD, Wallenstein MD, Bradford MA. 2010. Soil-carbon response to warming dependent on microbial physiology. Nature Geoscience. 3(5): 336-340.

Alm J, Schulman L, Walden J, Nykanen H, Martikainen PJ, Silvola J. 1999. Carbon balance of a boreal bog during a year with an exceptionally dry summer. Ecology. 80(1): 161-174. 
Andrus RE. 1986. Some aspects of Sphagnum ecology. Canadian Journal of BotanyRevue Canadienne De Botanique. 64(2): 416-426.

Arft AM, Walker MD, Gurevitch J, Alatalo JM, Bret-Harte MS, Dale M, . . Wookey PA. 1999. Responses of Tundra Plants to Experimental Warming: Meta-Analysis of the International Tundra Experiment. Ecological Monographs. 69(4): 491-511.

Aronson EL, McNulty SG. 2009. Appropriate experimental ecosystem warming methods by ecosystem, objective, and practicality. Agricultural and Forest Meteorology. 149(11): 1791-1799.

Baldocchi DD. 2003. Assessing the eddy covariance technique for evaluating carbon dioxide exchange rates of ecosystems: past, present and future. Global Change Biology. 9(4): 479-492.

Bartsch I, Moore TR. 1985. A preliminary investigation of primary production and decomposition in 4 peatlands near Schefferville, Quebec. Canadian Journal of Botany-Revue Canadienne De Botanique. 63(7): 1241-1248.

Billings WD. 1987. Carbon balance of Alaskan tundra and taiga ecosystems - Past, present and future. Quaternary Science Reviews. 6(2): 165-177.

Boisvert EA. 2009. Initiation and development of three Lake Superior coastal peatlands. Michigan Technological University, Houghton, MI.

Bridgham SD, Pastor J, Updegraff K, Malterer TJ, Johnson K, Harth C, Chen J. 1999. Ecosystem Control over Temperature and Energy Flux in Northern Peatlands. Ecological Applications. 9(4): 1345-1358. 
Bridgham SD and Richardson CJ. 2003. Endogenous versus exogenous nutrient control over decomposition and mineralization in North Carolina peatlands. Biogeochemistry. 65(2): 151-178.

Bridgham SD, Updegraff K, Pastor J. 2001. A comparison of nutrient availability indices along an ombrotrophic-minerotrophic gradient in Minnesota wetlands. Soil Science Society of America Journal. 65(1): 259-269.

Burrows EH, Bubier JL, Mosedale A, Cobb GW, PM. 2005. Net Ecosystem Exchange of Carbon Dioxide in a Temperate Poor Fen: A Comparison of Automated and Manual Chamber Techniques. Biogeochemistry. 76(1): 21-45.

Callaghan TV, Jonasson S. 1995. Arctic Terrestrial Ecosystems and EnvironmentalChange. Philosophical Transactions of the Royal Society of London Series aMathematical Physical and Engineering Sciences. 352(1699): 259-276.

Chapin FS. 1983. Direct and indirect effects of temperature on arctic plants. Polar Biology. 2(1): 47-52.

Chapin FS, BretHarte MS, Hobbie SE, Zhong HL. 1996. Plant functional types as predictors of transient responses of arctic vegetation to global change. Journal of Vegetation Science. 7(3): 347-358.

Chapin FS, Shaver GR, Giblin AE, Nadelhoffer KJ, Laundre JA. 1995. Responses of Arctic tundra to experimental and observed changes in climate. Ecology. 76(3): 694-711.

Chapman SJ, Thurlow M. 1996. The influence of climate on $\mathrm{CO}_{2}$ and $\mathrm{CH}_{4}$ emissions from organic soils. Agricultural and Forest Meteorology. 79(4): 205-217. 
Chapman SJ, Thurlow M. 1998. Peat respiration at low temperatures. Soil Biology \& Biochemistry. 30(8-9): 1013-1021.

Charman D. 2002. Peatlands and environmental change. Chichester, England: John Wiley \& Sons Ltd. $301 \mathrm{p}$.

Chimner RA, Welker JM, Morgan J, LeCain D, Reeder J. 2010. Experimental manipulations of winter snow and summer rain influence ecosystem carbon cycling in a mixed-grass prairie, Wyoming, USA. Ecohydrology. 3(3): 284-293.

Clymo RS. 1964. The Origin of Acidity in Sphagnum Bogs. The Bryologist. 67(4): 427431.

Clymo RS. 1970. The Growth of Sphagnum: Methods of Measurement. Journal of Ecology. 58(1): 13-49.

Clymo RS. 1992. Models of peat growth. Suo, 43: 127-136.

Clymo RS, Hayward PM. 1982. The ecology of Sphagnum. In: Smith AJE ed. Bryophyte ecology. London and New York: Chapman and Hall. p. 229-289.

Crum H. 1992. A focus on peatlands and peat mosses. Ann Arbor, MI. University of Michigan Press. 320 p.

Davidson EA, Janssens IA. 2006. Temperature sensitivity of soil carbon decomposition and feedbacks to climate change. Nature. 440(7081): 165-173.

Dorrepaal E, Aerts R, Cornelissen JHC, Callaghan TV, Van Logtestijn RSP. 2004. Summer warming and increased winter snow cover affect Sphagnum fuscum 
growth, structure and production in a sub-arctic bog. Global Change Biology. 10(1): 93-104.

Dorrepaal E, Aerts R, Cornelissen JHC, Logtestijn RSPV, Callaghan TV. 2006. Sphagnum modifies climate-change impacts on subarctic vascular bog plants. Functional Ecology. 20(1): 31-41.

DorrepaalE, Toet S, van Logtestijn RSP, Swart E, van de Weg MJ, Callaghan TV, Aerts R. 2009. Carbon respiration from subsurface peat accelerated by climate warming in the subarctic. Nature. 460(7255): 616-U679.

Eichenlaub VLH, Nurnberger FV, Stolle HJ. 1990. The climatic atlas of Michigan. Notre Dame, (IN): University of Notre Dame Press. 165 p.

EPA. United States Environmental Protection Agency [Internet]. 2010. Great Lakes Coastal Wetlands: Classification and Ranking of Great Lakes Coastal Wetlands. [Cited 2010 Dec 12]. Available from: http://www.epa.gov/ecopage/wetlands/glc/table2.pdf.

Faubert P. 2004. The Effect of Long-Term Water Level Drawdown on the Vegetation Composition and $\mathrm{CO}_{2}$ Fluxes of a Boreal Peatland in Central Finland. Department of Plant Biology, Laval University. 76 p.

Gignac LD, Nicholson BJ, Bayley SE. 1998. The utilization of bryophytes in bioclimatic modeling: Predicted northward migration of peatlands in the Mackenzie River Basin, Canada, as a result of global warming. Bryologist. 101(4): 572-587.

Gignac, LD, Vitt DH. 1994. Responses of Northern Peatlands to Climate Change: Effects on Bryophytes. Journal of the Hattory Botanical Laboratory. 15: 119-132. 
Gorham E. 1988. Canada's peatlands: their importance for the global carbon cycle and possible effects of "greenhouse" climatic waring. Transactions of the Royal Society of Canada V. 3:21-23.

Gorham E. 1991. Northern Peatlands: Role in the Carbon Cycle and Probable Responses to Climatic Warming. Ecological Applications. 1(2): 182-195.

Goulden ML, Crill PM. 1997. Automated measurements of $\mathrm{CO}_{2}$ exchange at the moss surface of a black spruce forest. Tree Physiology. 17(8-9): 537-542.

Gower ST, Krankina O, Olson RJ, Apps M, Linder S, Wang C. 2001. Net Primary Production and Carbon Allocation Patterns of Boreal Forest Ecosystems. Ecological Applications. 11(5): 1395-1411.

Gunnarsson U. 2005. Global patterns of Sphagnum productivity. Journal of Bryology. 27: 269-279.

Gunnarsson U, Granberg G, Nilsson M. 2004. Growth, Production and Interspecific Competition in Sphagnum: Effects of Temperature, Nitrogen and Sulphur Treatments on a Boreal Mire. New Phytologist. 163(2): 349-359.

Henry GHR, Molau U. 1997. Tundra plants and climate change: the International Tundra Experiment (ITEX). Global Change Biology. 3: 1-9.

Hill GB, Henry GHR. 2011. Responses of High Arctic wet sedge tundra to climate warming since 1980. Global Change Biology. 17(1): 276-287. 
Hoosbeek MR, van Breemen N, Berendse F, Grosvernier P, Vasander H, Wallen B. 2001. Limited effect of increased atmospheric $\mathrm{CO}_{2}$ concentration on ombrotrophic bog vegetation. New Phytologist. 150(2): 459-463.

Houghton JT. 2005. Global warming. Reports on Progress in Physics. 68(6): 1343-1403.

Houghton JT, Jenkins GEJ, Ephraums JJ. 1990. Climate change. The IPCC scientific assessment. Cambridge: Cambridge University Press.

Houghton JT, Meira Filho LG, Lee H, Callander BA, Haites E, . . . Maskell K. 1995. Climate Change 1994: Radiative Forcing of Climate Change and An Evaluation of the IPCC IS92 Emission Scenarios. Reports of Working Groups I and III of the Intergovernmental Panel on Climate Change. Cambridge (UK): Cambridge University Press.

Houghton RA, Woodwell GM. 1989. Global climatic-change. Scientific American. 260(4): 36-44.

IDcide. IDcide.com [Internet]. 2010. Local Information Data Center; Pequaming weather data; [cited 12.23.2010]. Available from : http://www.idcide.com/weather/mi/lanse.htm."

IPCC. 2007. Intergovernmental Panel on Climate Change: Climate Change 2007 Synthesis report. IPCC, Geneva, Switzerland. p. 43-54.

Kivimaki SK, Yli-Petays M, Tuittila ES. 2008. Carbon sink function of sedge and Sphagnum patches in a restored cut-away peatland: increased functional diversity leads to higher production. Journal of Applied Ecology. 45(3): 921-929. 
Laine A, Byrne KA, Kiely G, Tuittila ES. 2007. Patterns in vegetation and $\mathrm{CO}_{2}$ dynamics along a water level gradient in a lowland blanket bog. Ecosystems. 10(6): 890905.

Lambers H, Chapin FS, Pons TL. 1998. Plant Physiological Ecology. 1st ed. New York (NY): Springer. $520 \mathrm{p}$.

Lloyd J, Farquhar GD. 2008. Effects of rising temperatures and $\mathrm{CO}_{2}$ on the physiology of tropical forest trees. Philosophical Transactions of the Royal Society B-Biological Sciences. 363(1498): 1811-1817.

Lloyd J, Taylor JA. 1994. On the temperature-dependance of soil respiration. Functional Ecology. 8(3): 315-323.

Luxmoore RJ, Hanson PJ, Beauchamp JJ, Joslin JD. 1998. Passive nighttime warming facility for forest ecosystem research. Tree Physiology. 18(8-9): 615-623.

Marion GM, Henry GHR, Freckman DW, Johnstone J, Jones G, Jones MH, . . Virginia RA. 1997. Open-top designs for manipulating field temperature in high-latitude ecosystems. Global Change Biology. 3: 20-32.

Maxwell JB, Barrie LA. 1989. Atmospheric and Climatic Change in the Arctic and Antarctic. Ambio. 18(1): 42-49.

Melillo JM, Steudler PA, Aber JD, Newkirk K, Lux H, Bowles FP, ... Morrisseau S. 2002. Soil Warming and Carbon-Cycle Feedbacks to the Climate System. Science. 298(5601): 2173-2176. 
Mitchell JFB. 1989. The greenhouse-effect and climate change. Reviews of Geophysics. 27(1): 115-139.

Moore TR, Bubier JL, Frolking SE, Lafleur PM, Roulet NT. 2002. Plant Biomass and Production and $\mathrm{CO}_{2}$ Exchange in an Ombrotrophic Bog. Journal of Ecology. 90(1): 25-36.

Moore TR, Roulet NT, Waddington JM. 1998. Uncertainty in predicting the effect of climatic change on the carbon cycling of Canadian peatlands. Climatic Change. 40(2): 229-245.

Murray KJ, Harley PC, Beyers J, Walz H, Tenhunen JD. 1989. Water-content effects on Photosynthetic response of Sphagnum mosses from the foothills of the Philip Smith mountains, Alaska. Oecologia. 79(2): 244-250.

Myneni RB, Keeling CD, Tucker CJ, Asrar G, Nemani RR. 1997. Increased plant growth in the northern high latitudes from 1981 to 1991. Nature. 386(6626): 698-702.

Norby RJ, Kobayashi K, Kimball BK. 2001. Rising $\mathrm{CO}_{2}$ - future ecosystems Commentary. New Phytologist. 150(2): 215-221.

Oechel WC, Hastings SJ, Vourlitis G, Jenkins M, Riechers G, Grulke N. 1993. Recent change of Arctic tundra ecosystems from a net carbon-dioxide sink to a source. Nature. 361(6412): 520-523.

Oechel WC, Vourlitis GL, Brooks S, Crawford TL, Dumas E. 1998. Intercomparison among chamber, tower, and aircraft net $\mathrm{CO}_{2}$ and energy fluxes measured during the Arctic System Science Land-Atmosphere-Ice Interactions (ARCSS-LAII) 
Flux Study. Journal of Geophysical Research-Atmospheres. 103(D22): 2899329003.

Parish F, Sirin A, Charman D, Joosten H, Minayeva T, Silvius M, Stringer L. 2008. Assessment on Peatlands, Biodiversity and Climate Change: Main Report. Global Environment Centre \& Wetlands International.

Prentice IC, Sykes MT, Cramer W. 1991. The Possible Dynamic Response of Northern Forests to Global Warming. Global Ecology and Biogeography Letters. 1(5): 129135 .

Rochefort L, Vitt DH, Bayley SE. 1990. Growth, production, and decomposition dynamics of Sphagnum under natural and experimentally acidified conditions. Ecology. 71(5): 1986-2000.

Rydin H. 1997. Competition between Sphagnum species under controlled conditions. Bryologist. 100(3): 302-307.

Rydin H, Jeglum JK. 2006. The Biology of Peatlands. Oxford University Press. 354 p.

Shaver GR, Canadell J, Chapin FS, Gurevitch J, Harte J, Henry G, . . Rustad L. 2000. Global Warming and Terrestrial Ecosystems: A Conceptual Framework for Analysis. BioScience. 50(10): 871-882.

Silvola J, Alm J, Ahlholm U, Nykanen H, Martikainen PJ. 1996. CO 2 Fluxes from Peat in Boreal Mires under Varying Temperature and Moisture Conditions. Journal of Ecology. 84(2): 219-228.

Sjörs H. 1980. Peat on Earth: Multiple Use or Conservation? Ambio. 9(6): 303-308. 
Sonesso M, Carlsson BÅ, Callaghan TV, Halling S, Björn LO, Bertgren M, Johanson U. 2002. Growth of two peat-forming mosses in subarctic mires: species interactions and effects of simulated climate change. Oikos. 99(1): 151-160.

Szumigalski AR, Bayley SE. 1997. Net aboveground primary production along a peatland gradient in central Alberta in relation to environmental factors. Ecoscience. 4(3): 385-393.

Strack M, Price JS. 2009. Moisture controls on carbon dioxide dynamics of peatSphagnum monoliths. Ecohydrology. 2(1): 34-41.

Sullivan PF, Arens SJT, Chimner RA, Welker JM. 2008. Temperature and Microtopography Interact to Control Carbon Cycling in a High Arctic Fen. Ecosystems. 11(1): 61-76.

Zoltai SC, Vitt DH. 1995. Canadian Wetlands: Environmental Gradients and Classification. Vegetatio. 118(1/2): 131-137.

Titus JE, Wagner DJ, Stephens MD. 1983. Contrasting water relations of photosynthesis for 2 Sphagnum mosses. Ecology. 64(5): 1109-1115.

Toet S, Cornelissen JHC, Aerts R, van Logtestijn RSP, de Beus M, Stoevelaar R. 2006. Moss Responses to Elevated $\mathrm{CO}_{2}$, and Variation in Hydrology in a Temperate Lowland Peatland. Plant Ecology. 182(1/2): 25-40.

Updegraff K, Bridgham SD, Pastor J, Weishampel P, Harth C. 2001. Response of $\mathrm{CO}_{2}$ and $\mathrm{CH}_{4}$ Emissions from Peatlands to Warming and Water Table Manipulation. Ecological Applications. 11(2): 311-326. 
Ward SE, Ostle NJ, McNamara NP, Bardgett RD. 2010. Litter evenness influences shortterm peatland decomposition processes. Oecologia. 164(2): 511-520.

Vasander H. 1982. Plant biomass and production in virgin, drained and fertilized sites in a raised bog in southern Finland. Annales Botanici Fennici. 19(2): 103-125.

Weltzin JF, Harth C, Bridgham SD, Pastor J, Vonderharr M. 2001. Production and microtopography of bog bryophytes: response to warming and water-table manipulations. Oecologia. 128(4): 557-565.

Weltzin JF, Pastor J, Harth C, Bridgham SD, Updegraff K, Chapin CT. 2000. Response of Bog and Fen Plant Communities to Warming and Water-Table Manipulations. Ecology. 81(12): 3464-3478.

Verhoeven JTA, Liefveld WM. 1997. The ecological significance of organochemical compounds in Sphagnum. Acta Botanica Neerlandica. 46(2): 117-130.

Wheeler BD, Proctor MCF. 2000. Ecological Gradients, Subdivisions and Terminology of North-West European Mires. Journal of Ecology. 88(2): 187-203.

Wieder R, Vitt D. 2006. Boreal Peatland Ecosystems. Ecological Studies, Vol. 188: Berlin-Heidelberg Springer-Verlag. 435 p.

Wieder RK. 2001. Past, present, and future peatland carbon balance: An empirical model based on Pb-210-dated cores. Ecological Applications. 11(2): 327-342. 
Wofsy SC, Goulden ML, Munger JW, Fan SM, Bakwin PS, Daube BC, . . Bazzaz FA. 1993. Net Exchange of $\mathrm{CO}_{2}$ in a Mid-Latitude Forest. Science. 260(5112): 13141317.

Woodwell GM. 1995. Biotic feedbacks from the warming of the earth. In: Woodwell GM, McKenzie FT, editors. Biotic Feedbacks in the Global Climatic System: Will the Warming Feed the Warming? Oxford: Oxford University Press. p. 3-21.

Woodwell, GM, Whittaker RH. 1968. Primary Production in Terrestrial Ecosystems. American Zoologist. 8(1): 19-30.

Vourlitis GL, Oechel WC, Hastings SJ, Jenkins MA. 1993. A system for measuring insitu $\mathrm{CO}_{2}$ and $\mathrm{CH}_{4}$ flux in unmanaged ecosystems - an arctic example. Functional Ecology. 7(3): 369-379. 